\title{
Information for Establishing \\ Bioassay Measurements and Evaluations of Tritium Exposure
}

\author{
?O NOT MICROFILM \\ COVER
}

U.S. Nuclear Regulatory

Commission

Office of Nuclear Regulatory Research

A. Brodsky

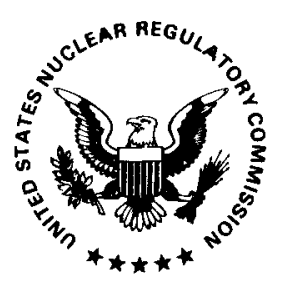




\section{DISCLAIMER}

This report was prepared as an account of work sponsored by an agency of the United States Government. Neither the United States Government nor any agency Thereof, nor any of their employees, makes any warranty, express or implied, or assumes any legal liability or responsibility for the accuracy, completeness, or usefulness of any information, apparatus, product, or process disclosed, or represents that its use would not infringe privately owned rights. Reference herein to any specific commercial product, process, or service by trade name, trademark, manufacturer, or otherwise does not necessarily constitute or imply its endorsement, recommendation, or favoring by the United States Government or any agency thereof. The views and opinions of authors expressed herein do not necessarily state or reflect those of the United States Government or any agency thereof. 


\section{DISCLAIMER}

Portions of this document may be illegible in electronic image products. Images are produced from the best available original document. 


\section{NOTICE}

\section{Availability of Reference Materials Cited in NRC Publications}

Most documents cited in NRC publications will be available from one of the following sources:

1. The NRC Public Document Room, 1717 H Street, N.W. Washington, DC 20555

2. The NRC/GPO Sales Program, U.S. Nuclear Regulatory Commission, Washington, DC 20555

3. The National Technical Information Service, Springfield, VA 22161

Although the listing that follows represents the majority of documents cited in NRC publications, it is not intended to be exhaustive.

Referenced documents available for inspection and copying for a fee from the NRC Public Document Room include NRC correspondence and internal NRC memoranda; NRC Office of Inspection and Enforcement bulletins, circulars, information notices, inspection and investigation notices; Licensee Event Reports; vendor reports and correspondence; Commission papers; and applicant and licensee documents and correspondence.

The following documents in the NUREG series are available for purchase from the NRC/GPO Sales Program: formal NRC staff and contractor reports, NRC-sponsored conference proceedings, and NRC booklets and brochures. Also available are Regulatory Guides, NRC regulations in the Code of Federal Regulations, and Nuclear Regulatory Commission Issuances.

Documents available from the National Technical Information Service include NUREG series reports and technical reports prepared by other federal agencies and reports prepared by the Atomic Energy Commission, forerunner agency to the Nuclear Regulatory Commission.

Documents available from public and special technical libraries include all open literature items, such as books, journal and periodical articles, and transactions. Federal Register notices, federal and state legislation, and congressional reports can usually be obtained from these libraries.

Documents such as theses, dissertations, foreign reports and translations, and non-NRC conference proceedings are available for purchase from the organization sponsoring the publication cited.

Single copies of NRC draft reports are available free upon written request to the Division of Technical Information and Document Control, U.S. Nuclear Regulatory Commission, Washington, DC 20555.

Copies of industry codes and standards used in a substantive manner in the NRC regulatory process are maintained at the NRC Library, 7920 Norfolk Avenue, Bethesda, Maryland, and are available there for reference use by the public. Codes and standards are usually copyrighted and may be purchased from the originating organization or, if they are American National Standards, from the American National Standards Institute, 1430 Broadway, New York, NY 10018. 


\section{Information for Establishing Bioassay Measurements and Evaluations of Tritium Exposure}

Manuscript Completed: December 1982

Date Published: June 1983

\section{A. Brodsky}

Division of Facility Operations

Office of Nuclear Regulatory Research

U.S. Nuclear Regulatory Commission

Washington, D.C. 20555
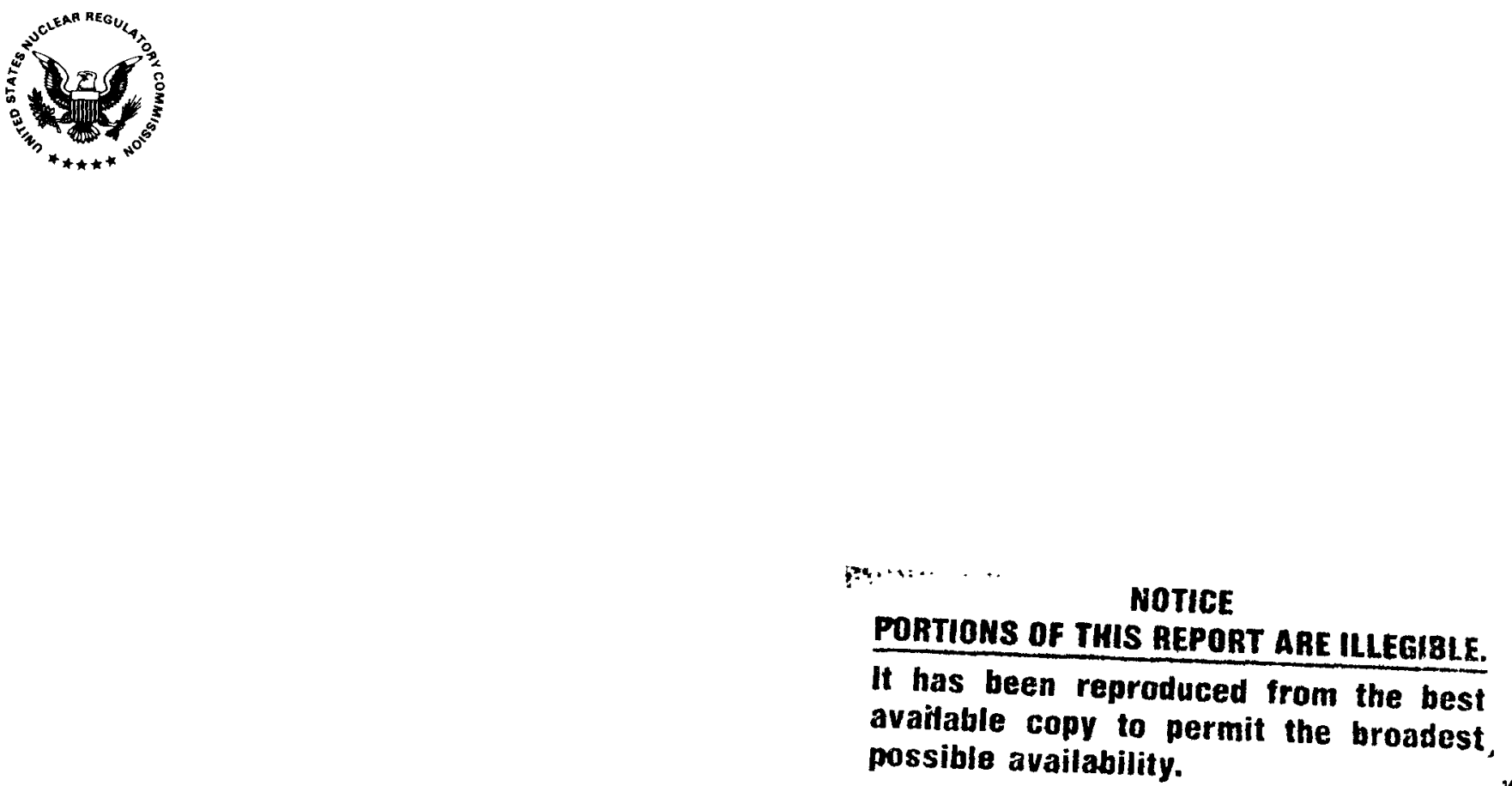

It has been reproduced trom the best available copy to permit the broadest, possible availability. 


\section{PURPOSE}

This report summarizes information and references used in developing regulatory guidance* on programs for the bioassay of tritium and provides information that may be useful to applicants and licensees in planning and conducting bioassay programs for tritium.

Any guidance in this document related to information collection activities has been cleared under OMB Clearance No. 3150-0014.

\section{GENERAL GUIDES ON INTERNAL DOSE LEVELS REQUIRING MONITORING}

Advisory and regulatory bodies have taken similar positions regarding the need for monitoring radiation workers potentially exposed to external penetrating radiation (Refs. 1 , pp. $84-85 ; 2$; 3). NRC regulations (Ref. 3) require that appropriate personnel dosimeters be provided if there is a likelihood of receiving within a calendar quarter a dose equivalent (DE) in excess of $25 \%$ of the quarterly maximum permissible dose. The International Commission on Radiological Protection (ICRP) suggests monitoring at 0.3 of the annual limit (Ref.2), which is about the same dose level, if averaged over time. Current NRC regulations (Ref. 3) are somewhat more conservative; for a whole body exposure, which is generally assumed in the case of an exposure to tritium gas** or tritiated water, this number is $25 \%$ of $5 / 4$ rem, or 0.3 rem per quarter.

Thus this DE ( 0.3 rem) is believed to be a reasonable guide number on which to base the need for a bioassay program. About $3 \mathrm{mCi}$ of tritiated water assimilated into the body tissue of a standard man will give this DE (or $1.8 \mathrm{mC}$ using an RBE*** of 1.7 rather than 1 (Refs. 4-6)). This is consistent for our purposes with the derived investigation level of $1.5 \mathrm{mC} i$ intake, which would deliver 0.25 rem with a quality factor $(Q)$ of 1.7 , as recommended in ICRP Reports 10 and $10 \mathrm{~A}$ (Refs. 4, 7). Although the ICRP has used $Q=1$ in recent publications, a review of radiobiological literature since the initial ICRP adoption of $Q=1$ indicates many experimental results suggesting a larger $Q$ (Ref. 6). Thus, $Q=1.7$ is retained in many installations in the United States as a more conservative factor consistent with ALARA (as low as reasonably achievable) principles.

*A draft regulatory guide, Task OP 713-4, "Applications of Bioassay for Tritium," was issued for comment in

**Immersion doses, with the skin as the critical organ, are not considered here, since the relative radiotoxicity used for tritium gas in structuring Table 1 has been chosen conservatively to assume that $0.1 \%$ tritiated water may be present. Reference 8 provides guidance for cases in which tritium gas might contain higher amounts of tritium oxide.

*** RBE stands for relative biological effectiveness of a given dose in rads for any type of radiation compared to the effectiveness (for a defined biological endpoint) of the same dose from x-rays of specified standard quality. Since RBE varies with so many biological and physical factors, the term "quality factor," designated by $Q$, has more recently been adopted for use in applied radiation protection to represent conservative corrections for variations in RBE of a specified type of radiation. 
Table 1

ACTIVITY LEVELS OR CONCENTRATIONS ${ }^{\mathrm{a}}$ ABOVE WHICH TRITIUM BIOASSAY PROGRAMS SHOULD BE PROVIDED

\begin{tabular}{|c|c|c|c|}
\hline Types of operation & $\begin{array}{l}\text { HTO }{ }^{b} \text { and Other Tritiated } \\
\text { Compounds (Including } \\
\text { Nucleotide Precursors) }\end{array}$ & $\begin{array}{l}\text { Tritium }\left(H T \text { or } T_{2}\right)^{C} \\
\text { Gas in Sealed } \\
\text { Process Vessels }\end{array}$ & $\begin{array}{l}\text { HTO Mixed with More } \\
\text { Than } 10 \mathrm{~kg} \text { of Inert } \\
\mathrm{H}_{2} \mathrm{O} \text { or } 0 \text { ther } \\
\text { Substances }\end{array}$ \\
\hline $\begin{array}{l}\text { Processes in open room or bench with } \\
\text { possible escape of tritium from } \\
\text { process vessels }\end{array}$ & $0.1 \mathrm{Ci}$ & $100 \mathrm{Ci}$ & $0.01 \mathrm{Ci} / \mathrm{kg}$ \\
\hline $\begin{array}{l}\text { Processes with possible escape of } \\
\text { tritium carried out within a fume } \\
\text { hood of adequate design, face veloc- } \\
\text { ity, and performance reliability }\end{array}$ & $1 \mathrm{Ci}$ & $1000 \mathrm{Ci}$ & $0.1 \mathrm{Ci} / \mathrm{kg}$ \\
\hline $\begin{array}{l}\text { Processes carried out within } \\
\text { gloveboxes that are ordinarily } \\
\text { closed but with possible release of } \\
\text { tritium from process vessels and } \\
\text { occasional exposure to contaminated } \\
\text { box and box leakage }\end{array}$ & $10 \mathrm{Ci}$ & $10,000 \mathrm{Ci}$ & $1 \mathrm{Ci} / \mathrm{kg}$ \\
\hline \multicolumn{4}{|c|}{ 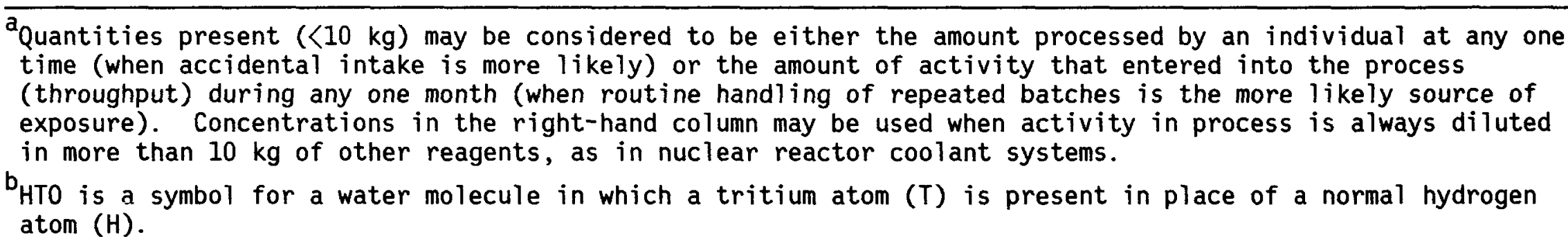 } \\
\hline \multicolumn{4}{|c|}{$\begin{array}{l}\mathrm{C}_{\mathrm{A}} \text { molecule of hydrogen gas contains two hydrogen atoms. Either one of these atoms may be replaced with } T \\
\text { to form HT, or two } \mathrm{T} \text { atoms may combine to form } \mathrm{T}_{2} \text { gas. } \\
\mathrm{d}_{\text {This assumes that adequate air monitoring has established that there is no tritium leakage or that no }} \\
\text { significant amount of tritium gas can be converted to HTO before intake. }\end{array}$} \\
\hline
\end{tabular}




\section{PROBABILITIES OF INTAKE AND LEVELS IN PROCESS REQUIRING BIOASSAY}

The need for tritium bioassay of employees depends in general on many interrelated factors such as the nature and amount of tritium in process at any time, the types of processing, the extent of other safeguards or facilities provided to prevent occupational exposures, and the probabilities that significant quantities of tritium may be inhaled or ingested with the particular materials, procedures, and facilities involved (Refs. 9-11). Thus, the choice of an optimum combination of safeguards, including bioassay, is a complex problem and should be carried out by the laboratory supervisor in consultation with a professional health physicist experienced in tritium operations. However, experience (Refs. 5, 12-16) with the processing and use of tritium in various forms suggests that the probability of intake is such that bioassays should be performed on persons working regularly with amounts greater than those in Table 1.* For amounts less than those in Table 1 , a determination of the need for bioassay may be based on the information summarized in this report and the references cited.

In attempting to derive the tritium activities handled or in process that would have an appreciable probability of resulting in an intake of $3 \mathrm{mCi} \mathrm{T}_{2} \mathrm{O}$ or HTO** per quarter, one is immediately confronted with a variety of parameters that affect the derivation. In many cases, these parameters cannot be estimated satisfactorily. Moreover, the potential for a serious accidental exposure is very difficult to assess even when all the conditions are factored in and impossible when conditions are only vaguely or generally defined. For these reasons, some conservatism must be built into such estimates. Thus, conservative assumptions regarding credible accidents together with the experience of bioassay programs in routine operation in various installations have been used to estimate the activity levels in process or introduced into process over a calendar quarter that call for bioassay according to Table 1. Some of the experience relating activity processed to intake is given in References 9, 15, and 16 . This experience and other information in the references cited may be helpful in deciding when bioassay should be provided for operations in the range of 0.1 to 1 times the values in Table 1 (see Item $b$ of Regulatory Position 1 in the draft regulatory guide).

The levels of operation with tritiated water above which bioassay checks or routine evaluations have been carried out may vary considerably between institutions (Refs. 9, 13). In some instances, there is evidence that requirements have been too stringent and have resulted in unnecessary costs for more analyses than a safe surveillance program needs (Ref. 13). In other cases, the lack of a suitable bioassay program at an early date may have been partly responsible for serious overexposures (Ref. 14). In one reference, levels of operation above 10 curies of HTO in volatile or dispersible form have been suggested to require consideration of at least occasional bioassay whenever the material in process is in a volatile or readily dispersible form and there is a possibility of its release and inhalation; this 10-curie level was

\footnotetext{
*Table 1 of this report is identical with Table 1 of Draft Regulatory Guide OP 713-4, "Applications of Bioassay for Tritium."
}

** $T$ represents tritium, an isotope of hydrogen. Either one or two $T$ atoms can substitute for hydrogen in a water molecule to form $\mathrm{T}_{2} \mathrm{O}$ or HTO, respectively. 
obtained partly by considering experience with plutonium and scaling up quantities eight orders of magnitude according to the relative dose per unit activity inhaled (Ref. 9). However, experience has shown that tritium as HTO can also penetrate certain protective gloves and be taken in through the skin unless gloves are washed frequently (Ref. 5, pp. 190-210). Also, incidents with smaller quantities of tritium have yielded measurable exposures that some institutions believe should be recorded for radiation monitoring purposes, even though these instances are rare and the cumulative exposures are small (Ref. 15).

Experience from accidental releases does indicate, however, that the probability of intake by inhalation would generally be much less than 10-5 of the material in process (Refs. 15-18). Assuming protection of hands and forearms in the case of tritium, these values from operational experience should also set a practical upper limit to the fraction of tritium inhaled compared to material in process. On the other hand, since tritium as HTO can readily be taken up through skin or inhaled (Ref. 19) and the intake of only about $5 \mathrm{mC} i$ could produce 1 rem (using $Q=1.7$ ), many installations have performed routine bioassay at this level or below for open operations with little or no additional containment. There is considerable opinion (Ref. 13) that bioassay services, at least on a sampling basis, should be considered at open-bench levels of operation above $10 \mathrm{mC} i$ per worker in process and should generally be required above $100 \mathrm{mCi}$ in process in order to achieve ALARA exposures unless the nature of the operation ensures additional containment or sufficent dilution with other process materials. Some experience (Ref. 15) with concentrations of tritium diluted in large volumes has also been used to establish bioassay criteria in Table 1 that are applicable to nuclear reactor workers. In any event, the values in Table 1 for activity levels in process above which a bioassay program for tritium is considered necessary are thus believed to be sufficiently low to make it unlikely that (with biweekly sampling) dose commitments exceeding 300 mrem per quarter (averaged over body water) would go undetected. Also, these criteria would not generally be considered unduly burdensome by most health physicists experienced in tritium monitoring (Ref. 13), particularly since Regulatory Position 4.2 of the regulatory guide permits converting to a quarterly sampling frequency if bioassay data and other monitoring indicate a low potential for tritium intake by the worker.

\section{RELATIVE RADIOTOXICITY AND HAZARD OF VARIOUS COMPOUNDS}

Recent reviews of the literature on the acute and chronic effects of tritium at the human, animal, tissue, cellular, and subcellular levels reveal that it is possible to assign ranges to the effectiveness of various tritiated compounds, HT or $T_{2}$ gas, and tritiated DNA precursors* relative to HTO in producing the various biological endpoints investigated (Refs. $6 ; 20 ; 21$, pp. $45-52 ; 22 ; 23$ ). The following tentative and conservative selection of "radiotoxicities" relative to HTO was made in 1977 for purposes of interim internal NRC guidance (Ref. 20): 1 for non-DNA precursors other than tritium gas, 10 for tritium organic compounds that are precursors to nucleotides that can be incorporated into DNA, and $1,000^{-1}$ for tritium gas ensured to be free of

\footnotetext{
${ }^{*} A$ molecule in one of the natural biochemical pathways that contains some tritium in place of hydrogen and that will end up in the deoxyribonucleic acid (DNA) molecules that constitute part of the genetic material of a cell.
} 
HTO or $\mathrm{T}_{2} \mathrm{O}$. For reasons given below, the relative toxicity of nucleotide precursors has now been taken as 1 relative to HTO. With this conservative selection (on the safe side) of relative radiotoxicity and experience with the actual human intakes of tritium from various types of processes (Refs. 5, 14-19), criteria have been developed in the regulatory guide for judging the need for bioassay monitoring of personnel handling various forms of tritium. Experience since 1977 with the interim guidance, comments from licensees and inspectors, more recent reviews and recommendations of professional and scientific groups (Refs. 6, 21-23), and information collected in drafting standards for tritium bioassay (Refs. 8, 20, 24-28) suggested the need for a revision of the interim guidance and its publication in the form of a regulatory guide.

The relative value for nucleotide precursors has been changed from 10 to 1 based partly on recent ICRP and NCRP reviews (Refs. 21-23). These reviews show that only a small fraction of a nucleotide precursor inhaled or ingested results in tritium-labeled DNA in cells. Only one-eighth of ingested ${ }^{3} \mathrm{H}$-thymidine survives catabolism and crosses the gut as thymidine (Ref. 21, p. 46); only $0.2 \%$ will end up in DNA and about $0.9 \%$ in other organic fractions, including those excreted in urine (Ref. 21). Furthermore, although large theoretical doses to cell nuclei may be calculated for relatively small amounts of activity, a review of radiobiological literature will show that endpoint effects per unit activity administered to animals are not significantly more frequent or severe than effects from intake of HTO. Furthermore, the nucleotide precursors are not likely to be involved in chemical processes that produce forms as volatile as HTO (Ref. 8, p. 11) and are thus not found to be as much of a hazard to the worker as previously believed. Thus it was possible to simplify Table 1 by including HTO and all organics in the same category. This decision is consistent for nucleotide precursors with the judgment of the Canadian group (Ref. 8, p. 11) developing tritium bioassay guidance, but Table 1 has been made much simpler (and slightly more conservative in some instances) than the Canadian approach.

\section{CALCULATION OF DOSES AND INTAKES FROM BIOASSAY DATA}

This section includes information and references that may be helpful in providing licensees with immediate interpretations of tritium bioassay data for purposes of determining the potential importance of internal exposures or for determining compliance with NRC regulations and license conditions. In the case of exposure to tritium oxide (both forms of tritiated water, $\mathrm{T}_{2} \mathrm{O}$ and HTO, will hereafter be abbreviated HTO), analytical sensitivities and data are available for calculating from bioassay data the internal doses to soft tissue or the tritium intakes. Uncertainties arise mainly from the selection of the appropriate quality factor $(Q)$ and the assumed times of intake when the exact times of exposure are not known. However, these uncertainties are usually smaller than for other nuclides. A brief summary of information on $Q$ (or RBE) is given in Section 5.1. Various mathematical formulations and computer programs for minimizing uncertainties due to different time patterns of intake are available in the literature.

In the case of tritium gas (elemental tritium) or tritiated compounds other than HTO, dose and intake calculations may have larger uncertainties owing to greater variability and uncertainty in deposition, uptake, and elimination from the body. The equations for quantitative calculations contain parameters selected 
to bias the calculations in the safer direction whenever uncertainties may be large. At the same time, information and references are given so that more exact calculations may be made when necessary parameters and exposure conditions are better known.

\subsection{Selection of Q (Quality Factor, Formerly QF)}

The original ICRP/NCRP recommendations (Ref. 29) used in formulating the NRC regulatory limits of exposure to airborne or waterborne radionuclides recommended an $R B E$ (now designated $Q$ when used as a single value for radiation protection purposes) of 1.7 for exposure of tissue to tritium beta rays, which are of very low energy (see physical data in Table 2). Subsequent ICRP reports continued to use $Q=1.7$ until 1969 (Ref. 30). Despite the ICRP recommendation in effect to use a $Q$ of 1 instead of the previously recommended value of 1.7 for tritium beta radiation, some radiobiological evidence at low dose rates in recent years has suggested that a $Q$ greater than 1 relative to gamma ray effects is appropriate (Refs. 6, 20). Human data are not available to distinguish between these two values, and many references and inquiries have shown that action levels and dose calculations in use in the United States for radiation protection purposes are still following derived urinary excretion values based on a $Q$ of 1.7 (Refs. 5, pp. 190-210; 12; 20). A Q of 1 may be more appropriate for estimating the potential for acute biological effects at higher doses, as suggested by the animal data (Refs. 20, 23), but a more recent experiment with rats resulted in an $L_{50}$ at 4 days of 1.86 and 3.72 kilorads for HTO and gamma rays, respectively (Ref. 31), as well as $Q$ values greater than one for other macroscopic biological endpoints.

Considering the human and animal data available, the probable variation within a range of 1 to 3 of $Q$ with dose rate and type of effect studied (Refs. 6 , $32,33)$, the desire for conservatism in establishing standards for radiation protection (Refs. 6, 32), the estimate that doses to organic long-term compartments may be up to 1.5 times that calculated for body water (Refs. 6, 34 ), and the desirability of avoiding unnecessary perturbations in alreadyfunctioning bioassay programs, it seems reasonable to accept the ICRP (Ref. 7 , pp. 29-30) derived investigation level (DIL) of $1.5 \mathrm{mC}$ intake as representing a dose commitment of $250 \mathrm{mrem}(1.7 \times 250$ if ICRP had used $Q=1.7$ ) and urinary elimination rates of $35 \mu \mathrm{Ci} / \mathrm{L}$ (initial), $13 \mu \mathrm{Ci} / \mathrm{L}$ at 14 days, and $4 \mu \mathrm{Ci} / \mathrm{L}$ at 30 days after a single intake (Refs. 7,35). The action points of $5 \mu \mathrm{Ci} / \mathrm{L}$ and $50 \mu \mathrm{Ci} / \mathrm{L}$ of Regulatory Position 5 of the draft regulatory guide would then bracket well these DILs of ICRP- 20 and $-10 \mathrm{~A}$ (Refs. 7, 4). The action point of $5 \mu \mathrm{Ci} / \mathrm{L}$ is also consistent with that used by major national laboratories (Ref. 36), and the $50 \mu \mathrm{Ci} / \mathrm{L}$ action level is the same as that independently adopted in Canada (Ref. 8, p. 11) for removal of an employee from work involving potential for whole body exposure.

The adoption of these DILs for single intake and the above dose commitment is also quantitatively consistent with the use of the original ICRP (Ref. 29) maximum permissible continuous body burden of $1 \mathrm{mC} i^{*}$ HTO for a continuous dose

ॠThe actual value of $1.2 \mathrm{mCi}$, giving a calculated dose rate of $100 \mathrm{mrem} /$ week to $43 \mathrm{kilograms}$ of body water and resulting in an equilibrium excretion rate of $28 \mathrm{\mu Ci} / \mathrm{L}$ of urine (using a 12-day biological half-life), was rounded off to 1 in the ICRP Committee II Report (Ref. 29). 
Table 2

\section{TRITIUM DECAY AND DOSE CONSTANT DATA*}
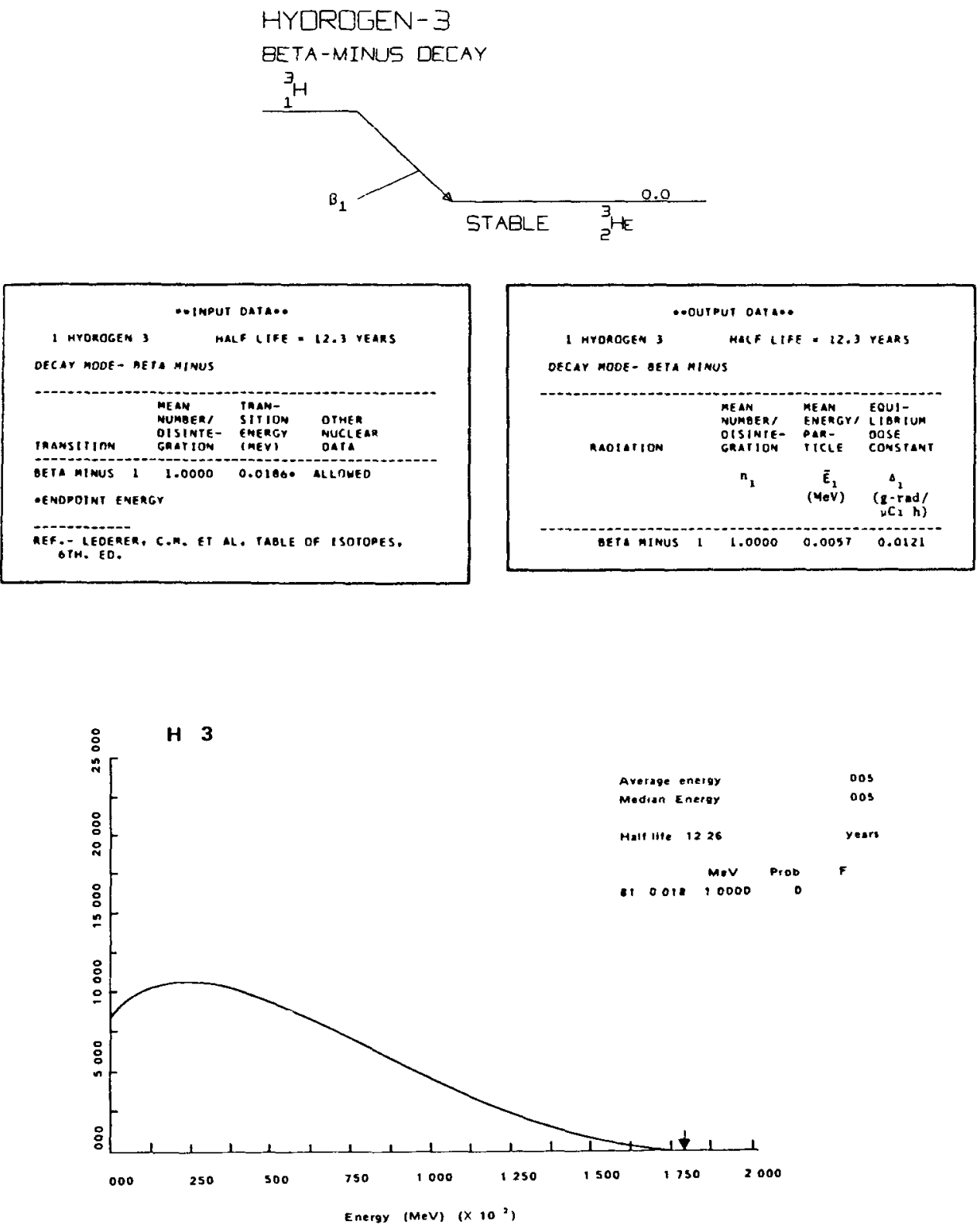

* The input-output data are from L. T. Dillman, "Decay Scheme Data and Dose Constants for Radionuclides of Importance in Radiological Science," Section 3.6, in Handbook of Radiation Measurement and Protection, Section A, Vol. 1, A. Brodsky, Editor, CRC Press, Boca Raton, Fla., 1979, p. 273. The particle spectrum is from 0. H. Hogan, P. E. Zigman, and J. L. Mackin, "Beta Spectra II. Spectrum of Individual Negatron Emitters," USNRDL-TR-802, U.S. Naval Radiological Defense Laboratory, San Francisco, Calif., December 16, 1964. 
rate of 100 mrem per week to body water, resulting in an equilibrium excretion rate of $28 \mu \mathrm{Ci} / \mathrm{L}$ (Ref. 5). For the 1959 standard man (Ref. 29), a 1-mCi HTO burden would be sustained by a continuous 40-hour per week occupational exposure to an air concentration of $5 \times 10^{-6} \mathrm{mCi} / \mathrm{mL}$ as $\mathrm{HTO}$, or $2 \times 10^{-3} \mathrm{mCi} / \mathrm{mL}$ of tritium gas (Ref. 5). The corresponding drinking water concentration in equilibrium with $1 \mathrm{mCi}$ in body water would be $0.1 \mu \mathrm{Ci} / \mathrm{mL}(100 \mu \mathrm{Ci} / \mathrm{L})$, allowing for loss of water by exhalation (Ref. 29). These ICRP values are consistent with the conversion more recently recommended by Moghissi, Patzer, and Carter (Ref. 35) for calculating environmental dose commitments to populations from urinary levels of tritium and with the more recent review of Till et al.

(Ref. 6) suggesting that a return to the use of $Q=1.7$ would be "more in line with the current 'conservative' approach to the assessment of dose."

\subsection{Dose and Intake Calculations for HTO}

\subsubsection{Relationships Between Dose Rate and Concentration of Radioactivity}

The dose rate to a mass $\mathrm{m}$ in grams containing $\mathrm{A} \mu \mathrm{C} i$ of radioactivity is (Ref. 7)

$$
R(t)=51.2 \frac{\varepsilon}{m} A \text { rem } / \text { day }
$$

where $\varepsilon$ is the effective absorbed energy per disintegration in $\mathrm{MeV}(\varepsilon=0.0057$ $x 1.7 \mathrm{MeV}$ for tritium*). The dose rate to water containing $\mathrm{C} \mu \mathrm{Ci} / \mathrm{L}$ of tritium is, assuming 1 liter $=1000$ grams,

$$
\begin{aligned}
R(t) & =51.2 \times \frac{0.0057 \times 1.7}{1000} C \mathrm{rem} / \text { day } \\
& =0.50 \mathrm{C} \mathrm{mrem} / \text { day }
\end{aligned}
$$

(This result would be $0.29 \mathrm{C} \mathrm{mrem} /$ day using $Q=1$. )

Tritium oxide (HTO) entering the body by ingestion, inhalation, or skin absorption quickly becomes uniformly distributed in the body water (Refs. $7 ; 22$, pp. $65-66 ; 37 ; 38)$. The dose to body water for HTO exposure is a conservative estimate of the overall whole body dose. ICRP recommended in 1959 the use of $43 \mathrm{~kg}$ of body water as the critical organ for HTO exposure, and that the dose to this "organ" be added to the whole body dose (Ref. 29). Since the kidneys do not discriminate between $\mathrm{H}_{2} \mathrm{O}$, HTO, HDO, ** or other water molecules, the measurement of the concentration of tritium in a urine sample yields an estimate of the concentration of tritium oxide in body water. Therefore, estimates of the HTO dose equivalent rate to whole body water can be obtained from urine sample measurements. If the concentration in urine as a function of

\footnotetext{
*This value was decreased from $0.010 \mathrm{MeV}$ when the ICRP recommended that the quality factor be lowered from 1.7 to 1.0 for low-energy electrons. Snyder et al. use $\varepsilon=0.0057 \mathrm{MeV}$ for tritium (Ref. 39). The higher value of $Q$ is used here for reasons given in Section 5.2.

**HDO represents a water molecule with deuterium (hydrogen-2) replacing one of the hydrogen atoms.
} 
time, $c(t)$, is known, the dose $D$ to the body water of an individual in the interval $t_{1}$ to $t_{2}$ can be calculated from

$$
D\left(t_{1}-t_{2}\right)=\int_{t_{1}}^{t_{2}} R(t) d t=0.50 \int_{t_{1}}^{t_{2}} c(t) d t \text { mrem }
$$

where times are in days and $c(t)$ is the urine concentration in microcuries of tritium per liter of urine.

The whole body occupational exposure limit for HTO is 5 rems per year (Ref. 29). The constant concentration of HTO in body water, and therefore urine, which if maintained for 50 weeks would result in an annual dose of 5 rems (Ref. 37), is

$$
C=\frac{D}{0.50\left(t_{2}-t_{1}\right)}=\frac{5000}{0.50 \times 350} \cong 28 \mu \mathrm{Ci} / \mathrm{L}
$$

which is the "benchmark" urine level still most used in health physics programs in the United States. This value is $48.5 \mu \mathrm{Ci} / \mathrm{L}$ for $Q=1$.

The concentration in body water (and urine) following a single intake of HTO that would ultimately result in the ICRP's recommended investigation level of one-twentieth of the yearly dose limit (250 mrem) (Ref. 37) is (assuming tritium oxide is eliminated from the body exponentially)

$$
C=\frac{D / 20}{0.29 \int_{0}^{\infty} e^{-\lambda t} d t} \mu C i / L
$$

(where $0.29 \mathrm{C}$ is the dose rate in rem/day taken from Equation 2 for $Q=1$ ).

With the recommended (Ref. 22, pp. 65-66) half-time $(t=\ln 2 / \lambda$ ) of 10 days, the derived investigation level for tritium in urine is

$$
C=\frac{5000 / 20}{0.29 \times 10 / 7 n_{2}}=60 \mu \mathrm{Ci} / \mathrm{L}
$$

or $35 \mu \mathrm{Ci} / \mathrm{L}$ for $Q=1.7$.

For individuals subjected to a chronic intake whose last two urine concentration measurements are $C_{1}$ and $C_{2}$, the average tritium concentration $C$ in the interval between the times these samples were obtained is

$$
\begin{aligned}
& c=\left(C_{1}+C_{2}\right) / 2, \text { where } \\
& C_{1}=c\left(t_{1}\right), \text { and } \\
& c_{2}=c\left(t_{2}\right) .
\end{aligned}
$$

Therefore, the calculated dose $D_{C a}$ in the interval $t_{1}$ to $t_{2}$ may be obtained from: 


$$
D_{\text {cal }}=\frac{0.50\left(C_{1}+C_{2}\right)\left(t_{2}-t_{1}\right)}{2} \text { mrem }
$$

\subsubsection{Single-Intake Dose Commitment}

If an individual's urine concentration $C_{1}$ on day $t_{1}$ is above $50 \mu \mathrm{Ci} / \mathrm{L}$ and he is removed from work involving a possible risk of tritium or whole body exposure, the effective half-time $T_{1}$ for fritium in this individual may be determined from urine samples and used to estimate more accurately the total dose from $t_{1}$ on from the formula

$$
\begin{aligned}
D & =\underset{t_{1}}{0.50 c_{1}^{\infty} \int e^{-\lambda t} d t \text { mrem }} \\
& =\left(0.50 c_{1} / \lambda\right) e^{-\lambda t_{1}}
\end{aligned}
$$

where $\lambda=0.693 / T_{\frac{1}{2} \text { eff }}$. For $t=0$, Equation 8 simplifies to

$$
D=0.50 C_{1} / \lambda \text {, }
$$

which is the same as $0.50 C_{1} T_{\text {mean }}$, where $T_{\text {mean }}=1 / \lambda$ is the mean life of a tritium atom in the body.

Also,

$$
\begin{aligned}
D & =0.50 \mathrm{C}_{1} \mathrm{~T}_{\frac{1}{2} \mathrm{eff}} / 0.693 \\
& =0.72 \mathrm{C}_{1} \mathrm{~T}_{\frac{1}{2} \mathrm{eff}}
\end{aligned}
$$

since the mean life is $1 / 0.693=1.44$ times the half-life.

The $T_{1 / 2 f}=10$ days for reference man may be used for planning or evaluation purposes when an individual's follow-up urine samples are not available. Then, the dose commitment from a single intake giving an initial urine concentration of $1 \mu \mathrm{Ci} / \mathrm{L}$ within 1 to 2 days after exposure may be estimated as

$$
D=0.72 \times 10 \times 1=7.2 \text { mrem per } \mu \mathrm{Ci} / \mathrm{L}
$$

Some real exposure situations consist of a series of single intakes occurring on known days of operation. If the intakes are spaced far enough apart (i.e., 40 or more days), the total dose commitment from all intakes in a year could be calculated simply by using the conversion factor of Equation 10 and summing all of the total dose commitments calculated from each urine concentration measurement. For more frequent or continuous exposures, radioactivity from previous exposure days or periods has not been eliminated to insignificant levels. In these cases, Equation 7 provides a simple method for estimating the dose committed during any period between two urine sample measurements. Since the effective half-life of HTO in the body is only 10 days, it should be adequate for most radiation protection purposes to record either total dose commitments or actual internal doses received during 
a particular calendar year. Other more elaborate schemes for computing internal doses or dose commitments from HTO intakes with various time patterns are available in the literature (Refs. 37, 40).

Because adoption by the Environmental Protection Agency (EPA) and NRC of all or part of the more recent ICRP recommendations on internal dose limitation is under consideration and discussion, it is often necessary to compare results of internal dose calculations from the old and new methods. For HTO, the comparison is relatively simple. The major differences in the calculation of the internal dose from a given intake are that the dose in ICRP- 30 is averaged over all soft tissue $(63,000 \mathrm{~g}$ ) (Ref. 22, pp. 65-66), rather than only the body water mass (now $42 \mathrm{~kg}$ (Ref. 41) rather than $43 \mathrm{~kg}$ (Ref. 29) for reference man) and $Q$ is taken as 1 rather than 1.7. Since the risk weighting factor for all soft tissue is the same as that for the whole body in ICRP-30, the new ICRP weighting procedure has no effect on calculations of internal dose and annual limit of intake from a pure HTO exposure.

Thus, under the new ICRP recommendations, the dose commitment calculation of Equation 10 becomes

$$
\begin{aligned}
D(\text { new ICRP }) & =\frac{43}{63} \times \frac{1}{1.7} \times 7.2 \\
& =2.9 \mathrm{mrem} \text { per } \mu \mathrm{Ci} / \mathrm{L} \text { at } t=0
\end{aligned}
$$

which, when corrected to SI derived units, is

$$
\begin{aligned}
D(\text { new ICRP }) & =\frac{2.9 \mathrm{mrem} /(\mu \mathrm{Ci} / \mathrm{L})}{100 \mathrm{rem} / \mathrm{Sv}} \times \frac{10^{-3} \mathrm{rem} / \mathrm{mrem}}{3.7 \times 10^{4} \mathrm{~Bq} / \mu \mathrm{Ci}} \\
& =7.8 \times 10^{-10} \mathrm{~Sv} /(\mathrm{Bq} / \mathrm{L}) \text { at } \mathrm{t}=0
\end{aligned}
$$

for urine samples taken near the time $(t=0)$ of a single intake (but after the concentration of tritium in body water has reached equilibrium).

The relationship between a single intake by inhalation ( $p$ lus skin absorption) or by oral ingestion and urine concentration may be obtained under the new ICRP recommendations as follows:

1. An intake of $1 \mathrm{~Bq}$ would be rapidly absorbed throughout body water for any route of intake. For HTO vapor inhaled, an exception exists to the usual lung model consideration because about $95-100 \%$ of inhaled HTO is immediately trapped in lung tissues and distributed by the blood throughout the body (Refs. $21 ; 22$, pp. 65-66; 42). Essentially no inspired HTO is exhaled because the ubiquitous $\mathrm{H}_{2} \mathrm{O}$ competes for evaporation from lung surfaces with the extremely low mokar concentration of HTO. Thus, the body water concentration for a 1-Bq intake becomes:

$$
C=\frac{1 \mathrm{~Bq}}{42 \mathrm{~L}}=0.0238 \mathrm{~Bq} / \mathrm{L}
$$

2. The concentration in Equation 12 will be found in urine excreted within a few hours after intake. Thus a urine sample should be taken at the end of the workday when HTO exposure is known or suspected. 
3. Multiplying Equation 12 by Equation 11 gives the single-intake dose commitment:

$$
\begin{aligned}
D_{50}(\text { new ICRP }) & =0.0238 \times 7.8 \times 10^{-10} \\
& =1.85 \times 10^{-11} \mathrm{~Sv} / \mathrm{Bq} \text { intake }
\end{aligned}
$$

4. Since the total uptake (including skin absorption) is 1.5 times that inhaled under the new ICRP-30, the equation for inhalation (corrected for additional HTO absorbed through skin) becomes:

$$
\begin{aligned}
D_{50}(\text { new ICRP }) & =1.5 \times 1.85 \times 10^{-11} \\
& =2.8 \times 10^{-11} \mathrm{~Sv} / \mathrm{Bq} \text { inhaled }
\end{aligned}
$$

The value in Equation 13 is in fair agreement with the $1.7 \times 10^{-11}$ in Eckerman et al. (Ref. 43) as derived from ICRP-30 methods (Ref. 22) within numerical rounding errors. The user should note that, in the ICRP-30 Supplement (Ref. 44), the same values of committed dose equivalent in soft tissue, $1.7 \times 10^{-11} \mathrm{~Sv} / \mathrm{Bq}$, are given for both oral and inhalation intakes. These are to be considered the total intakes. In the case of persons exposed to HTO in air, a quantity equal to that breathed in would be assumed to be taken into the body through exposed skin under the earlier ICRP recommendations (Ref. 29), whereas later data and ICRP-30 assume the dose to be increased by only a factor of 1.5 to account for skin absorption.

The single intake concentration and dose values are summarized as follows:

$$
\text { 1. Dose conversion }(\mathrm{Sv} / \mathrm{Bq})=1.73 \times 10^{-11}
$$

This conversion derives from the fact that an annual limit of intake (ALI) of $2.9 \times 10^{9} \mathrm{~Bq} /$ year is calculated to produce $0.05 \mathrm{~Sv}$ ( $5 \mathrm{rem}$ ).

2. In earlier units, using $Q=1.7$,

Dose conversion ( $\mathrm{rem} / \mathrm{mC} \mathrm{i})$

$$
\begin{aligned}
& =1.73 \times 10^{-11} \times 100 \mathrm{rem} / \mathrm{Sv} \times 3.7 \times 10^{7} \mathrm{~Bq} / \mathrm{mCi} \times 1.7 \\
& =0.11 \mathrm{rem} / \mathrm{mCi} \text { intake }
\end{aligned}
$$

(This value is close to the $1.25 \times 10^{-4} \mathrm{rem} / \mu \mathrm{Cj}$ obtained by Dunning et al. (Ref. 42).)

3. With return to averaging dose over body water and using the earlier ICRP effective half-life of 12 days, this conversion would be

$$
\mathrm{rem} / \mathrm{mCi}(1959)=0.11 \times \frac{63}{43} \times \frac{12}{10}=0.193
$$

Thus, for example, the earlier ICRP recommendations (Ref. 29), which are still the basis for current regulatory concentration limits, are consistent with a dose of about 1 rem per $5 \mathrm{mC} i$ of intake. This means that, for exposure 
in air, equal skin and inhalation intake would yield a $10-\mathrm{mCi}$ total intake giving a total dose commitment of 2 rem if $5 \mathrm{mCi}$ were inhaled. For $1 / 3$ intake through skin, $5 \mathrm{mCi}$ inhaled would correspond to a 7.5-mCi intake, giving a dose commitment of 1.5 rem. For radiation protection purposes, the earlier ICRP recommendations still provide the more conservative (safer) estimates of internal dose among the several methods of calculation that have been proposed (Ref. 45).

\subsection{Dose and Intake Calculations for Elemental ${ }^{3} \mathrm{H}_{2}$ Gas}

\subsubsection{Summary of Dose Information for ${ }^{3} \mathrm{H}_{2}$ Gas}

Although, as discussed later in the section, elemental tritium in the air inspired into the lung may have much lower radiobiological significance than the dose calculated at the lung surface would indicate, ICRP recommends controlling tritium gas exposure in the following way:

\section{DAC (Submersion) for Elemental Tritium*}

Exposure to elemental tritium in air during any year is limited by consideration of stochastic effects in the lung as follows

$$
{ }^{w_{1}} \text { ung } \mathrm{H}_{\text {lung }} \int \mathrm{C}(\mathrm{t}) \mathrm{dt} \leqq 0.05 \text { Sv }
$$

where $w_{1 \text { ung }}$ is the weighting factor for lung given in Table 2.1, Chapter 2;

$\mathrm{H}_{\text {lung }}$ (in Sv $\mathrm{m}^{3} \mathrm{~Bq}^{-1} \mathrm{~h}^{-1}$ ) is the dose-equivalent rate to lung from exposure to unit concentration of tritium in air (i.e., $1 \mathrm{~Bq} \mathrm{~m}^{-3}$ );

$C(t)$ (in $B q \mathrm{~m}^{-3}$ ) is the concentration of elemental tritium in air at any time $t$ and the limits on integration are over a working year.

For convenience, the Commission*t recommends a value of DAC for elemental tritium which is $1 / 2000$ th of the greatest value of $\int C(t) d t$ that satisfies relationship (3.4). A worker may be exposed to concentrations of elemental tritium in air greater than the DAC provided that the conditions in relationship (3.4) are satisfied.

With a specific effective energy taken as $5.7 \times 10^{-6} \mathrm{MeV} / \mathrm{g}$ per transformation, the ICRP calculates a dose equivalent rate in lung per unit concentration of elemental tritium in air of $9.9 \times 10^{-15} \mathrm{~Sv}-\mathrm{m}^{3} / \mathrm{Bq}$-hour. This value is equivalent to

$$
\begin{aligned}
& 9.9 \times 10^{-15} \frac{\mathrm{Sv}}{\mathrm{h}-\mathrm{Bq} / \mathrm{m}^{3}} \times 100 \frac{\mathrm{rem}}{\mathrm{Sv}} \times 3.7 \times 10^{4} \frac{\mathrm{Bq}}{\mu \mathrm{Ci}} \times 10^{6} \frac{\mathrm{mL}}{\mathrm{m}^{3}} \\
& \quad=3.66 \times 10^{-2}(\mathrm{rem} / \text { hour }) /(\mu \mathrm{Ci} / \mathrm{mL}),
\end{aligned}
$$

\footnotetext{
${ }^{*}$ Quoted from ICRP-30 (Ref. 22, p. 10).

**The reader should note here that Commission in this quotation denotes the ICRP, not the NRC.
} 
for $a \mathrm{Q}$ of 1 , For $w w_{1}=0.12$, the ICRP obtains a weighted committed dose equivalent rate in lungl per unit concentration of elemental tritium in air of $1.2 \times 10^{-15} \mathrm{~Sv}-\mathrm{m}^{3} / \mathrm{Bq}$-hour. The concentration of ${ }^{3} \mathrm{H}_{2}$ gas that would give an exposure by submersion exceeding regulatory limits (Ref. 3) if inhaled by a worker for 40 hours per week for 13 weeks is $2 \times 10^{-3} \mu \mathrm{Ci} / \mathrm{mL}$. (If a portion of this gas were HTO, the corresponding limit (Refs. 3, 29) for that portion would be $5 \times 10^{-6} \mu \mathrm{Ci} / \mathrm{mL}$.) At $2 \times 10^{-3} \mu \mathrm{Ci} / \mathrm{mL}$, the dose rate to $1 \mathrm{ung}$ calculated from Equation 18 would be only $3.66 \times 10^{-2} \times 2 \times 10^{-3}=7.3 \times$ $10^{-5} \mathrm{rem} / \mathrm{hour}$, or about $0.07 \mathrm{mrem} /$ hour, which is small compared to dose rates that could deliver appreciable fractions of maximum permissible doses to lung tissue. Thus, the newer ICRP methods of calculation indicate that present regulatory concentration limits are very conservatively on the side of safety. This is justified, however, by the fact that commercial tritium gas of ten contains $0.5 \%$ HTO vapor, and in the event that any tritium released as a gas would be oxidized to HTO before inhalation by workers, a lower concentration limit than that for tritium gas would be applicable.

For the elemental gas portion of a tritium exposure (which should be determined by suitable air monitoring (Ref. 8 , p. 11) when quantities in process exceed those in Table 1), the following information may be helpful in calculating intake and internal dose from bioassay data.

Anderson and Langham (Ref. 46) reached the following conclusions from their studies of physiological kinetics and effects of tritium gas and tritiated water:

1. The hazard from the exposure to tritium gas was at least 1,000 times less than that from tritiated water;

2. The greatest exposure hazard from tritium gas would result from its conversion to its oxide prior to intake;

3. The beta dose rate to the 1- $\mu \mathrm{m}$ respiratory surface of lung is largely ineffective, as indicated by the fact that 135,000 calculated rems to the lung surfaces in mice produced no histological evidence of damage;

4. The contributions to whole body dose from dissolved tritium gas in body fluids and from tritium biologically oxidized to HTO are about equal;

5. The doses from bremsstrahlung and auto-oxidation of tritium by its own radiation field can be neglected.

The hazard from exposure to even larger amounts of pure tritium gas was not judged to be a lethal one (Ref. 5). A 10-second exposure to pure tritium gas $(2.6 \mathrm{Ci} / \mathrm{mL}$ ) would result in a dose of only about 6 rems. (At the breathing rate of $20 \mathrm{~L} / \mathrm{min}$ of reference man under light activity (Ref. 41), the 10-second exposure would amount to about $(10 / 60) \mathrm{min} \times 20,000 \mathrm{~mL} / \mathrm{min} \times 2.6 \mathrm{Ci} / \mathrm{mL}=8,700 \mathrm{Ci}$ breathed in. However, such an exposure could be lethal if only a small fraction (perhaps $0.1 \%$ ) were converted to HTO before inhalation.

It was also calculated (Ref. 5) that, if the air in a room were $10 \%$ tritium gas, a 10-minute exposure would result in a dose of about 40 rems. (In a small laboratory with a volume of 150 to $300 \mathrm{~m}^{3}$, a $10 \%$ tritium atmosphere 
would correspond to a release of 4 to $8 \times 10^{7} \mathrm{Ci}$. The 10-minute exposure would amount to an inhalation of $0.1 \times 20 \mathrm{~L} / \mathrm{min} \times 10 \mathrm{~min} \times 2.6 \times 10^{3} \mathrm{Ci}$ of $\mathrm{T}_{2}$ per liter $=52,000 \mathrm{Ci}$ of $\mathrm{T}_{2}$ gas.)

The above estimates of intake may be compared with the data of Pinson and Anderson (Ref. 47), which show that a man breathing an atmosphere containing $9 \mu \mathrm{Ci} / \mathrm{mL}$ of tritium as $\mathrm{HT}$ for 100 minutes reached a urinary leve 7 of $14 \mu \mathrm{Ci} / \mathrm{L}$. Using the ICRP values (Refs. 7,35 ) of $35 \mu \mathrm{Ci} / \mathrm{L}$ in urine corresponding to 0.25 rem dose commitment from HTO, the experimenter inhaled a quantity of

$9 \mu \mathrm{Ci} / \mathrm{mL} \times 1000 \times 20 \mathrm{~L} / \mathrm{min} \times 100 \mathrm{~min}=18 \mathrm{Ci}$ of $\mathrm{HT}$ gas,

and the HTO produced by biological oxidation of 0.003 to $0.004 \%$ (Refs. 21, 47) of this HT gas in the body produced a dose commitment of

$$
\frac{14}{35} \times 0.25 \text { rem }=0.1 \text { rem }
$$

Therefore, the inhalation of 52,000 curies of tritium gas, as postulated in the above example, would give, for $Q=1.7$, a dose commitment of

$$
\frac{52,000}{18} \times 0.1 \text { rem }=290 \text { rems }
$$

It is probable that, for most persons, this dose spread out over the effective lifetime of HTO in the body would not lead to lethality.

Even the 10-second exposure to pure tritium gas involved an inhalation of 8700 curies. Using Pinson and Anderson's results and ICRP values, this quantity inhaled should give a dose commitment of

$$
\frac{8700}{18} \times 0.1 \mathrm{rem}=48 \mathrm{rems}
$$

in good agreement with the 40 rems estimate of Anderson and Langham (Refs. 5, 46). These quantities (and resulting doses) of HTO in the body resulting from inhalation by man of tritium gas are also consistent with the data of Pinson and Langham (Ref. 48). Thus, using data for man from Pinson and Langham, a dose to body water calculated from HTO in urine may be interpreted in terms of tritium gas inhaled (if other data ensure no HTO was present during inhalation) by multiplying the dose commitment in rem by $18 / 0.1=180$ to obtain the total amount of tritium gas inhaled in curies. However, to obtain the total dose, the dose from dissolved tritium gas should be calculated as shown below and added to the dose calculated from HTO in urine.

\subsubsection{Calculation of Dose Contribution from Dissolved Tritium Gas}

The solubility of $\mathrm{H}_{2}$ in water is $1.91 \mathrm{~mL} / 100 \mathrm{~g}$ at $25^{\circ} \mathrm{C}$ or $1.89 \mathrm{~mL} / 100 \mathrm{~g}$ at $50^{\circ} \mathrm{C}$ (Ref. 49). Using $1.90 \mathrm{~mL} / 100 \mathrm{~g}$ at body temperature and a specific 
activity of 2.6 curies $T_{2}{ }^{*}$ per milliliter of pure gas at a pressure of 1 atmosphere, the solubility in body water under equilibrium conditions becomes $0.0494 \mathrm{Ci} / \mathrm{g}$. Thus, the concentration per unit volume, relative to that in pure gas in equilibrium with water, would be about

$$
\frac{0.0494 \mathrm{Ci} / \mathrm{mL} \text { water }}{2.6 \mathrm{Ci} / \mathrm{mL}}=0.019
$$

at $25^{\circ} \mathrm{C}$, or slightly less at body temperature. This is in fair agreement with the estimate of $1.65 \%$ concentration (Ref. 46) in body tissues relative to concentration of tritium in air. The rate of dissolution of tritium in blood in equilibrium with inspired air may be assumed to follow a 4-minute half-time of uptake (Ref. 50), so approximate equilibrium would be reached within 10 to 20 minutes after exposure to a constant concentration, or the concentration in blood will remain lower than equilibrium concentrations for short exposure times. Solubilities for $\mathrm{H}_{2}$ gas are assumed sufficiently accurate to use for HT or $\mathrm{T}_{2}$ gas for dose estimation purposes (Ref. 51).

The dose rate in blood (or body water) at equilibrium with a constant pressure of $1 \mathrm{~atm} \mathrm{~T}_{2}$ is

$0.0494 \mathrm{Ci} / \mathrm{g} \times 3.7 \times 10^{10} \mathrm{~d} / \mathrm{sec}-\mathrm{Ci} \times 0.0057 \mathrm{MeV} / \mathrm{d} \times 1.6 \times 10^{-6} \mathrm{erg} / \mathrm{MeV}$

$$
\begin{aligned}
& =17 \mathrm{ergs} / \mathrm{g}-\mathrm{sec} \\
& =0.17 \mathrm{rad} / \mathrm{sec}
\end{aligned}
$$

For a concentration of $9 \mu \mathrm{Ci} / \mathrm{mL}$ in inspired air, as in the experiment of Pinson and Anderson (Ref. 47), the equilibrium exposure rate would be proportional to the partial pressure of tritium gas. Thus the dose rate from dissolved HT during the 100-minute exposure period would be approximately:

$$
\begin{aligned}
& \left(\frac{1}{2} \times 0.17 \mathrm{rad} / \mathrm{sec} \text { for } \mathrm{HT}\right) \times \frac{9 \times 10^{-6} \mathrm{Ci} / \mathrm{mL}}{\frac{1}{2} \times 2.6 \mathrm{Ci} / \mathrm{mL}} \\
& =5.8 \times 10^{-7} \mathrm{rad} / \mathrm{sec}, \\
& \quad \text { or } 3.5 \times 10^{-5} \mathrm{rad} / \mathrm{min}
\end{aligned}
$$

Thus, during the duration of the 100-minute inhalation experiment (Ref. 47), 18 curies of HT were inhaled, delivering a calculated dose to blood of about $3.5 \times 10^{-5} \times 100=0.0035 \mathrm{rad}(1.7 \times 0.0035=0.006 \mathrm{rem})$ and a dose commitment

$$
\begin{aligned}
& \text { ₹At } 1 \text { atmosphere, the number of } T \text { atoms per milliliter is } \\
& \begin{aligned}
\mathrm{N} & =\frac{2 \times 6.023 \times 10^{23}}{22,400 \mathrm{~mL}}=5.38 \times 10^{19} \text {, and the activity is } \\
\mathrm{A} & =\lambda \mathrm{N} / 3.7 \times 10^{10}=\frac{0.693}{12.3 \times 365 \times 24 \times 3600} \frac{5.38 \times 10^{19}}{3.7 \times 10^{10}} \\
& =2.6 \mathrm{Ci} / \mathrm{mL}(1.3 \text { for } \mathrm{HT})
\end{aligned}
\end{aligned}
$$


(measured from bioassay samples) from the HTO formed by biological oxidation of about 0.1 rem, as obtained above. By comparison, the dose to the lung during this 100-minute inhalation period would be, by present ICRP methods as in Equation 18 but with $Q=1.7$,

\section{$3.66 \times 10^{-2}(\mathrm{rem} / \mathrm{hr}) /(\mu \mathrm{Ci} / \mathrm{mL}) \times 9 \mu \mathrm{Ci} / \mathrm{mL} \times 1.7 \times(100 / 60) \mathrm{hr}=0.93 \mathrm{rem}$}

Using ICRP weighting factors (Ref. 22, p.6), this exposure would give a total weighted dose equivalent of $0.006+0.1+0.12(0.93)=0.22$ rem. This calculation does not take into account tritium compartments resulting from tritiation of organic molecules in vivo or absorbed tritium gas that does not leave the system once the tritium concentration in inspired air is reduced, but the dose from these compartments is expected to be very small. The review by Till et al. (Ref. 6) supports the suggestions by Rohwer and the NCRP (Refs. 21, 23) that the dose to organic compartments can be adequately accounted for by multiplying the dose from HTO by a factor of 1.2 .

Thus, the internal dose from exposure to HT or $T_{2}$ gas would be 5,000 to 10,000 times lower than the internal dose from exposure to the same integrated air activity of HTO. For exposure times of 1 minute or less (typical of single releases in the laboratory), relative doses from tritium gas will be even lower as a result of the finite time required for diffusion of the gas into the blood (Ref. 50) compared to the instantaneous absorption of inhaled HTO (Ref. 6).

\subsection{Doses and Intakes of Tritium Compounds (Other than Nucleic Acid Precursors)}

Although the doses and effects from tritium compounds are more complex to investigate or predict than for tritiated water, many studies have surprisingly indicated that these compounds are usually not much more toxic than tritiated water and are often considerably less radiotoxic as a result of more rapid elimination from the body (Ref. 5). Tritiated corticosteroids were found on the basis of estimated organ doses to be 30 times less radiotoxic than tritiated water (Ref. 52). Tritiated folic acid was estimated to be twice as toxic as tritiated water based on results from the administration of these compounds to rats (Ref. 53). Shaw, in a private communication quoted in Vennart (Ref. 54, p. 429), has indicated that injections of the tritiated sex hormones oestradiol and testosterone result in smaller doses in all organs of the rats than those from equal injections of tritiated water. There is also an absence of appreciable hematologic changes in patients after intravenous doses of 10 curies of tritiated tetrasodium 2-methy1-1,4-naphthaquinol diphosphate (Refs. 5, 55). A 10-curie dose of tritiated water would have been expected to deliver about 1,000 rem to the bone marrow and would probably have exceeded the more chronic tritium exposures that Seelentag (Ref. 14) considered the primary causes of death in two cases.

Since tritiated water is the major catabolic product of most of the labeled compounds that enter the body (Ref. 34), exposures of workers to these compounds may be monitored by bioassay of urine with the likelihood that a major part of the dose may be interpreted as dose from HTO. This practice has been used in laboratories (Ref. 56) where employees are exposed to higher levels of tritium during production of these tritiated compounds. The additional factor of 1.2 may be used to account for the dose to organic compartments (Refs. 6, pp. 38-41; $57 ; 58$ ). Since tritiated compounds are generally less volatile than HTO and less easily absorbed through the skin, it seems reasonable for purposes of 
establishing criteria for bioassay programs to assume that the relative radiotoxicity of tritiated organic compounds is about the same as that for HTO; the actual hazard for a given quantity in process may often be much less.

\subsection{Doses and Intakes from Tritiated Compounds Concentrating in Ce11 Nuclei}

In Section 4, some background information was given to show how tritiated DNA precursors and other compounds that concentrate in cell nuclei may be considered in about the same overall hazard category as HTO and may be approximately evaluated from measurements of HTO in urine. This section reviews some information and references that may be useful in dose and intake evaluations for exposure to these special compounds.

A number of authors had earlier suggested that compounds such as tritiated thymine, thymidine, or other nucleotide precursors that would tend to concentrate in the DNA of cells might deliver far greater doses than tritiated water and present a far greater hazard per millicurie of intake by persons working with these compounds (Refs. 59-65), although recent NCRP reports (Refs. 21, 23) indicate that the overall risks from working with these compounds is probably not greater than those from working with HTO. Barber (Ref. 64) deduced that the maximum permissible concentration (MPC) for tritiated thymidine should be about 10-4 to 10-5 times the MPC for tritiated water, but this result was derived from calculations of an assumed maximum number of permitted disintegrations in the cells of a human composed completely of cell nuclei using Dewey and coworkers' (Ref. 66) negative finding that 30 disintegrations per cell from tritiated thymidine did not significantly increase chromosomal aberration frequencies. Berry et al. (Ref. 61) suggested that, based on cell survival studies, tritiated thymidine should be regarded as a material of moderately high toxicity comparable to I-131; this suggestion would place tritiated thymidine in a category requiring about 1,000 times the protection factors applicable to HTO (Ref. 9).

Guild (Ref. 65) calculated that tritiated thymidine can deliver doses to the chromosomes from 50 to 50,000 times those delivered by an equal activity of tritiated water; however, Dewey et a1. (Ref. 67) suggest that the effectiveness for breaking chromosomes is about the same for thymidine incorporated into DNA as for tritiated water or cobalt-60 gamma radiation. Also, 1,700 tritium disintegrations originating in DNA were required to produce one visible chromosome aberration (Ref. 66).

Lambert (Ref. 68), based on a review of previous literature as well as his own experiments (Refs. 68-70), concludes that the maximum permissible annual intake of tritiated thymidine is about $20 \mathrm{mCi}$. This intake of $20 \mathrm{mCi}$ may be compared with the annual intake of $25 \mathrm{mCi}$ of HTO that would give a dose commitment of 5 rems (integrating the intake by standard man breathing at MPC for one year (Ref. 29)).

Wade and Shaw (Ref. 62) have shown that 24 hours after stomach intubation of $1 \mu \mathrm{Ci}$ quantities of tritiated thymidine, the average total body activity was $51 \%$ of the ingested activity and the nonvolatile activity was only $8 \%$ of the ingested activity. After subcutaneous injection, several times more activity was retained in spleen, testes, and small intestine, relative to retention 
after oral ingestion over days $1,2,4$, and 8 ; about the same relative retention for injection as for ingestion was obtained for liver, kidney, and muscle. The nonvolatile activity was assumed to be retained mostly in the cell nuclei of these tissues as reported by others (Refs. 71-75). Assuming that nonvolatile activity was dispersed through all cell nuclei, Wade and Shaw (Ref. 62) calculated the maximum dose to nuclei from their data to be the dose to nuclei of liver, which reached about 0.2 rad per microcurie of ingested tritiated thymidine. Scaled up to the body weight of standard man, this would be 0.2 rad per $2.8 \mathrm{mC} i$ ingested; for comparison, the calculated dose to body water from ingesting $2.8 \mathrm{mCi}$. of HTO would be 0.28 rad -- slightly higher than the dose to nuclei from tritiated thymidine assuming all of the nonvolatile tritium is taken up in all cell nuclei of liver.

Then, arbitrarily assuming that only $5 \%$ of liver cells actually contain the observed quantity of nonvolatile tritium and adopting the conclusion of Bond and Feinendegen (Ref. 76) that the RBE of intranuclear tritium is probably close to one, Wade and Shaw (Ref. 62) calculated a dose equivalent to nuclei of 1.25 rem per $1 \mathrm{mC} i$ of tritiated thymidine ingested. They then compared this tritiated thymidine dose to a stated dose of 1.25 rem per $20 \mathrm{mCi}$ of HTO ingested and concluded that "...tritiated thymidine is more hazardous as an internal emitter than tritiated inorganic molecules such as water or hydrogen gas by at least a factor of 20." However, if the intake of HTO required to give 1.25 rems is calculated from ICRP data (Refs. 7, 29) but with $Q$ equal to 1 and $100 \%$ uptake of HTO, the comparable dose of HTO becomes $12.4 \mathrm{mC} i$ to give 1.25 rems -- not 20 as given by Wade and Shaw (Ref. 62). Moreover, the assumption that only $5 \%$ of the nuclei contain the tritium amounts to a proportionate reduction of the number of cells at risk in the "critical" tissue. Bond, Feinendegen, and coworkers (Refs. 76, 77), as well as Lambert (Ref. 68), cite evidence that somatic risk may be estimated on the basis of average dose to cell nuclei, or the product of average dose to cells at risk times the number of cells at risk. Thus, if the dose calculated by Wade and Shaw were averaged over all cell nuclei or, equivalently, the fractional number of cells at risk were taken into account by an appropriate weighting factor, the number of millicuries of ingested tritiated thymidine to produce a dose equivalent of 1.25 rems for somatic risk evaluation purposes would be increased to $20 \mathrm{mCi}$, and the relative "radiotoxicity" of tritiated thymidine would actually be less than that of tritiated water.

Lambert found that tritiated thymidine was only 3 times as effective as HTO per microcurie, even when it was injected intraperitoneally, for decreasing the production of primary resting spermatocytes in mouse testes (Refs. 68, 69). In the same set of experiments, the mice were also subjected to whole body irradiation and irradiation of testes alone, with little difference in effect.

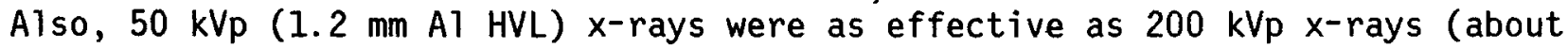
$12 \mathrm{~mm} \mathrm{Al} \mathrm{HVL).} \mathrm{When} \mathrm{the} \mathrm{dose} \mathrm{rate} \mathrm{of} 200 \mathrm{kVp} x$-rays was decreased at the same rate as that from $H T O$, the effect of 30 rads of $x$-radiation was equivalent to that from $20 \mu \mathrm{Ci}$ injected per gram of body weight. The RBEs obtained in these experiments ranged from 1.3 to 2.4. The calculated initial dose rate from $20 \mathrm{\mu Ci} / \mathrm{g}$ body weight would be $20 \times 3.6 \mathrm{rems} /$ week $^{\star}=72 \mathrm{rems} / \mathrm{week}$. For a

*0btained using the ICRP values (Refs. 7, 29) that $1.2 \mathrm{mCj} / 43,000 \mathrm{~g}$ of body water yields a dose rate of $100 \mathrm{mrem} /$ week or, for a single intake, yields a dose commitment of 100 mrems $\times 1.44 \times 10 / 7=205$ mrems using the ICRP-10 values for biological half-life (Ref. 7). 
biological half-life in the mouse of 2 days, this would amount to a dose during the 72-hour experiment of

$$
\begin{aligned}
\text { Dose }(72 \text { hours }) & =\int_{t=0}^{72} \frac{72 \text { rems } / \text { week }}{168 \mathrm{hr} / \text { week }} \mathrm{e}^{-0.693 \mathrm{t} / 2 \times 24} \mathrm{dt} \\
& =\frac{72}{168} \times \frac{48}{0.693}\left[\mathrm{e}^{-0.693(0) / 2}-\mathrm{e}^{-0.693(72) / 48}\right] \\
& =19 \text { rems }(19 / 1.7=11 \text { rads })
\end{aligned}
$$

The dose during the earlier 19-hour period, when perhaps the spermatogonial cells are in more sensitive stages, would be even lower when averaged over body water. Lambert (Ref. 69) obtained his doses to cell nuclei from track autoradiographs, correcting to dose in rads absorbed within the nuclear volume, which indicates for tritiated water that spermatagonial cell nuclei receive the same dose from tritiated water as calculated from the average dose to body water. (The calculated dose above, based on an assumed 2-day biological half-life in the mouse, gives an $\mathrm{RBE}=30 \mathrm{rads} / 11=2.7$, close to the higher value given by Lambert.)

Although the absorbed tritiated thymidine was contained mostiy in cell nuclei (Ref. 69), only a small fraction of the administered thymidine reached cell nuclei, so that the relative dose to nuclei per administered microcurie was such that cell effects per unit administered dose were only about 3 times greater for tritiated thymidine than for tritiated HTO.

Thus the ratio of the radiotoxicity of tritiated thymidine to that of HTO would be only 3 from these experiments, regardless of RBE or calculated doses to cell nuclei.* Furthermore, although the spermatogonia are particularly sensitive to radiation and responses may be observed for calculated doses as low as about 2 rads from tritium (Ref. 77), these rapidly proliferating cells would perhaps also be more capable of recovery and can sustain considerable depletion without loss of ability to survive or regenerate to full capacity (Refs. 68, 69).

In another set of experiments, Lambert and Clifton (Ref. 70) studied the ingestion of tritiated thymidine in rats and concluded that tritiated thymidine administered by ingestion gave the highest dose to bone marrow cells, about 34 times the dose given by tritiated water. Thus, proper laboratory practice should include procedures and equipment that preclude ingestion by persons working with these materials.

In a further set of experiments studying the effects on production of resting primary spermatocytes, Lambert (Ref. 68) shows that, al though highspecific-activity tritiated thymidine exhibits the greatest (spermatogonial)

\footnotetext{
*In a later paper, Lambert (Ref. 68) states that the relative radiation doses averaged over the testes were in the ratio of 1.5 to 1 for tritiated thymidine compared to tritiated water; for the relative doses to the cell nuclei (of spermatogonia), the corresponding ratio was 6.4 to 1 .
} 
cell-killing effect per injected microcurie among the several organic compounds studied, the concept of average dose to the mouse testes could be used within a factor of five to estimate the hazard from the compounds studied: tritiated thymidine, uridine, methionine, and HTO. His main conclusion from these and previous experiments is that "...to a first approximation, there is no great difference in cell-killing effects during 90 hours exposure between the compounds studied relative to injected activity." He also reviews previous work of others and indicates that although earlier papers "indicated that tritiated thymidine should be considered several orders of magnitude more toxic to mammalian cell systems than tritiated water... later work has disproved this concept...," and yet, "...there are still reports published suggesting that, on the basis of dose calculation, tritiated thymidine should be considered an extremely hazardous material." Thus, Lambert concludes, both from literature review and his own experiments, that tritiated thymidine is not more than five times as toxic per injected microcurie as other tritiated compounds or HTO.

Feinendegen and Bond (Ref. 78) have updated their review (Ref. 76) of the effects of tritium incorporated in DNA, cell nuclei, and other cell components and conclude, consistent with their earlier evaluation, that cell-killing effects can be explained on the basis of the average radiation dose delivered to the cell nucleus. The effect of transmutation of $\mathrm{H}-3$ to $\mathrm{He}-3$ after incorporation of tritiated thymidine or cytosine into cell nuclei was estimated to be much lower than the ionization effect from beta decay and is not easiry observed. Recoil effects of tritium atoms decaying when bound to DNA are also deemed to be negligible (Ref. 23, p. 116).

Tritium bound within the DNA of E. Coli was more effective in cell killing than that bound within the protein around the DNA core. Also, tritium decaying in DNA ( ${ }^{3} \mathrm{H}$-thymidine) was about twice as effective in reducing survival of Chinese hamster fibroblasts as tritium incorporated in ribonucleic acid (RNA) ( ${ }^{3} \mathrm{H}$-uridine). The effectiveness of beta decay was sometimes found to depend on the position of the tritium atom in the pyrimidine ring (Ref. 78). Tritium in the 5 position, but not in the 6 position, of cytosine was found effective in mutation induction in E. Coli and bacteriophage.

Tritiated uridine was more effective in inducing mutations in $E$. Coli at low temperatures (arginine reversion) and in Drosophila, when $\mathrm{H}-3$ was incorporated in the 5 rather than the 6 position. The mutation probability in E. Coli for the 6-to-5 position change rose from $0.28 \times 10^{-8}$ per decay per cell beyond the value of $0.67 \times 10^{-8}$ for tritium-methyl-thymidine in DNA. Since there was no significant difference in lethal effects of the two uridines, the 5 position effectiveness was in this case attributed to a transmutation effect in the $5 \%$ to $6 \%$ of the uracil that was converted to cytosine and incorporated into the DNA of the nucleus. However, except for the intake of tritiated precursors that specifically introduce ${ }^{3} \mathrm{H}-5$-cytosine, ${ }^{3} \mathrm{H}-6$-thymidine, or ${ }^{3} \mathrm{H}-2$-adenine into DNA, it seems that hazards may be estimated purely on the basis of absorbed beta dose (Ref. 23, p. 101).

In a review of the relative toxicity and permissible concentrations of tritium and its compounds, Osborne (Ref. 38) has summarized the evidence explaining why, although some of the tritium from HTO or other compounds may concentrate in DNA or other cell molecules, the net effect of the exposure has never been observed to be more than about 3 times that expected from a calculation of dose 
to body water from an equivalent activity of HTO. Osborne (Ref. 38) suggests, for example, that although folic acid and tritiated thymidine may give three times the dose to cell nuclei as the same intake to blood of tritiated water (as shown by Vennart in Reference 54), the spatial concentration of that tritium absorbed into cell nuclei is offset by catabolism of most of the tritiated compound before incorporation into nuclei. Moreover, seven-eighths of ingested thymidine would be catabolized in the gut, and additional catabolism of tritiated DNA precursors would take place in tissue before they could be incorporated into cell nuclei.

After intravenous injection of tritiated thymidine at a level of $1 \mu \mathrm{Ci} / \mathrm{g}$ body' weight (the minimum showing effects on bone marrow cell turnover rates with no marrow cell depletion in Sprague-Dawley rats), autoradiographic and radiochemical analyses showed that $27 \%$ of nucleated cells were labeled; the average calculated dose to the nuclei of labeled cells over the effective time until cell killing was 6 rads (Ref. 76). The dose averaged over all nuclei of the nucleated cells was about 1.5 rads. This may be compared to an average dose of about 0.3 rad to all body water (and nuclei as well) if $1 \mu \mathrm{Ci} / \mathrm{g}$ were injected as HTO. Thus the average dose to cell nuclei from injected tritiated thymidine was only about 5 times the average dose to body water (and also approximately to cell nuclei) that would have been delivered from the same injected activity of HTO. Bond and Feinendegen (Ref. 76) compare (from these experiments) a maximum dose of 25 to 35 rads to the most highly labeled cell nuclei (young megakaryocytes) with the 46 rads to marrow of mice that would produce definite changes in the DNA content of marrow (Ref. 79). However, the mouse marrow endpoint seems more severe than that of Bond and Feinendegen, and the species is different.

In a later review by Cronkite, Robertson, and Feinendegen (Ref. 77), the authors again confirm earlier conclusions (Ref. 76) as follows:

1. The absorbed dose concept holds down to the order of 10-11 grams or less, and somatic effects can be predicted on this basis.

2. The distribution of tritium atoms incorporated into DNA as tritiated thymidine (and ion pairs from the beta particles) are randomly distributed as far as dose calculations for the purpose of predicting somatic effects are concerned.

3. Every part of the cell nucleus lies within one tritium beta range of some part of a chromatid, and the nucleus contains no sizable contiguous insensitive volume of a radius exceeding the effective range of tritium betas $(1$ to $2 \mu \mathrm{m})$.

4. The origin of tritium beta tracks in, or their close juxtaposition to, the DNA molecule does not appear to enhance the degree of somatic effects.

In this later review, data available on the various types of somatic and genetic effects as produced by HTO and tritiated thymidine are again summarized and seem to indicate that doses to cell nuclei from the tritium beta particles, whether or not they originate from tritium atoms within DNA, can account for the effects produced. Also, the dosage from beta particles originating from DNA tritium does not seem to be more than about 5 times as effective as the 
same dose delivered by tritium atoms distributed in HTO within body water (and the water of the cell protoplasm and nucleus).

The review cited Johnson and Cronkite's study (Ref. 80 ) in which mice (Swiss Albino) injected with 1 and $5 \mu \mathrm{Ci}$ tritiated thymidine per gram of body weight at 6 to 12 weeks of age showed no significant difference in tumor incidence compared to that for unirradiated controls or controls given 400 roentgens of whole body gamma radiation. (Of course, considering the number of animals used in these experiments, detection of small changes in incidence would not be expected.)

The review again indicates that tritiated thymidine is almost surely not more than 10 times as radiotoxic as tritiated water per injected microcurie for various biological endpoints in animals, including acute and chronic somatic effects, as well as for cytogenetic effects. The relative radiotoxicity might even be lower for ingestion, inhalation, or absorption through skin than for injection. Thus, although the conditions of exposure and the nature of the tritiated nucleotide involved are important in determining dose and risk, for radiation protection purposes, it would be safe to assume, under unknown conditions, that the weighted dose equivalent commitment was not more than 10 times and probably not more than 3 times that calculated for the whole body HTO dose commitment from measurements of HTO in urine.

\section{6. $\quad$ CONCLUSIONS}

When compared on the basis of equal microcurie intakes under occupational exposure conditions, tritiated thymidine may be assumed to be not more than a factor of 10 more radiofoxic than tritiated water. 0ther tritiated organic compounds may be assumed to be about the same as tritiated water in relative radiotoxicity for purposes of hazard evaluation and establishing good safety practices. Actual relative radiotoxicities will depend on the type and form of compound taken into the body, the age of the exposed individual, and the biological endpoint considered. However, some earlier expectations of a much higher effectiveness of tritiated DNA precursors relative to HTO are not borne out by experimental results. Effects of concentration on DNA precursors are not as high as originally supposed, and transmutation and recoil effects have been judged by the NCRP to be unimportant. Furthermore, catabolism of DNA precursors and other organic compounds after normal modes of entry into the body, rapid turnover of tritium incorporated in DNA with each cell division, repair mechanisms, and other factors tend to compensate for the higher nuclear concentration of that portion of tritiated DNA precursors that reach cells during DNA synthesis. Guidance on the calculation of doses from tritium concentrated in cell nuclei is available in the recent NCRP review (Ref. 23). Good radiation safety practice and design should always provide adequate additional safety factors to allow for uncertainties in these assumptions regarding the ranges of relative radiotoxicities.

In the case of elemental tritium gas, doses may be calculated to lung and soft tissue as indicated in this report only when auxiliary measurements or survey data either ensure that no HTO is present or ascertain the exact proportion of HTO in the exposure so that it can be properly accounted for in estimating doses and intakes. Table 3 summarizes information useful in 
estimating doses and intakes from bioassay data on tritium. Reference 81 also provides methods of calculating internal doses from intakes of tritium.

Guidance on management, quality control, and recordkeeping in bioassay programs is available from ANSI (Ref. 82) and NCRP (Ref. 83). Procedures for radiometric and radiochemical measurements and data evaluation are abundant in the literature (Refs. 84-91). 
Table 3

TRITIUM DOSE AND INTAKE CALCULATIONS FROM BIOASSAY DATA

\begin{tabular}{|c|c|c|c|c|c|c|c|}
\hline Form & $\begin{array}{l}\text { Max. Dose }{ }^{a} \\
\text { Commitment per } \\
\text { Inhaled } \\
\text { Microcurie }\end{array}$ & $\begin{array}{l}\text { Max. Dose } \\
\text { Commitment per } \\
\text { Ingested } \\
\text { Microcurie }\end{array}$ & \multicolumn{2}{|c|}{$\begin{array}{r}10 \text { CFR Part } 20 \\
\text { Occupational } \\
\end{array}$} & $\begin{array}{l}\text { ICRP } \\
\text { Annual } \\
\text { Limit of In- } \\
\text { take by Inha- } \\
\text { lation or } \\
\text { Ingestion }\end{array}$ & $p-30$ & $\begin{array}{l}\text { Single Intake To Give 1-rem Dose } \\
\text { Commitment and Initial Urine } \\
\text { Concentration }\end{array}$ \\
\hline HTO & $0.0004 \mathrm{rem} / \mu \mathrm{Ci} i^{\mathrm{c}}$ & $\begin{array}{l}0.0002 \mathrm{rem} / \mu \mathrm{Ci} \\
\text { (Equation } 17 \text { ) }\end{array}$ & $\begin{array}{l}5 \times 10^{-6} \mu \mathrm{Cj} / \mathrm{mL} \\
(S \text { and } \mathrm{I})\end{array}$ & $0.1 \mu \mathrm{Ci} / \mathrm{mL}$ & $\begin{array}{l}3 \times 10^{9} \mathrm{~Bq} \\
(0.081 \mathrm{Ci}) \\
\text { oral or } \\
\text { inhalation }\end{array}$ & $\begin{array}{l}8 \times 10^{5} \mathrm{~Bq} / \mathrm{m}^{3} \\
\left(2.16 \times 10^{-5}\right. \\
\mu \mathrm{Ci} / \mathrm{mL} \text { inhala- } \\
\text { tion, corrected } \\
\text { for skin } \\
\text { absorption }\end{array}$ & $\begin{array}{l}5 \mathrm{mC} i \text { intake per rem; urine con- } \\
\text { centrations are } 116 \mu \mathrm{C} i / L \text { at } 1 \text { hour }\end{array}$ \\
\hline $\begin{array}{l}\text { Gas } \\
\text { (Elemental) }\end{array}$ & $\begin{array}{l}2 \times 10^{-8} \text { rem } / \mu \mathrm{Ci} \\
\text { (to body water) } \\
+6.2 \times 10^{-9} \mathrm{rem} / \mu \mathrm{Ci} \\
\text { (weighted dose } \\
\text { equivalent to lung) } \\
\text { (also account for } \\
\text { presence of HTO, } \\
\text { if any) }\end{array}$ & -- & $\begin{array}{l}2 \times 10^{-3} \mu \mathrm{Ci} / \mathrm{mL} \\
\text { (submersion) }\end{array}$ & -- & $\begin{array}{l}4.8 \times 10^{13} \mathrm{~Bq} \\
\left(1.3 \times 10^{3} \mathrm{Ci}\right)^{\mathrm{e}}\end{array}$ & $\begin{array}{l}2 \times 10^{10} \mathrm{Bg} / \mathrm{m}^{3} \\
(0.54 \mu \mathrm{i} / \mathrm{mL}) \\
\text { (submersion) }\end{array}$ & -- \\
\hline $\begin{array}{l}\text { Nucleic } \\
\text { Acid } \\
\text { Precursors }\end{array}$ & $\begin{array}{l}\text { Probabiy }<0.00024 \\
\text { rem } / \mu \mathrm{Ci} \text { weighted } \\
\text { equivalent (eval- } \\
\text { uate actual reten- } \\
\text { tion if urine } \\
>50 \mu \mathrm{Ci} / \mathrm{L} \text { ) }\end{array}$ & $\begin{array}{l}\text { Probably }<0.00024 \\
\text { rem } \mu \mathrm{C} \text { i weighted } \\
\text { equivalent (eval- } \\
\text { uate actual reten- } \\
\text { tion if urine } \\
>50 \mu \mathrm{Ci} / \mathrm{L} \text { ) }\end{array}$ & - & -- & $\begin{array}{l}0.020 \text { Ci (see } \\
\text { Refs. } 68,72 \text { ) } \\
\text { (reduce to } 1 / 50 \\
\text { for injection) } \\
\text { (see also } \\
\text { Ref. } 22 \text {, } \\
\text { pp. 14-15, } \\
\text { pp. 65-67) }\end{array}$ & - & $\begin{array}{l}\text { Probably not less than } 4 \mathrm{mCi} \text { intake } \\
\text { by inhalation or ingestion to give } \\
1 \text { rem weighted dose equivalent, } \\
\text { yielding at least about } 100 \mu \mathrm{Ci} / \mathrm{L} \\
\text { HTO at } 1 \text { hour (see Ref. } 22, \text { p. } 66 \text { ) }\end{array}$ \\
\hline $\begin{array}{l}\text { Other } \\
\text { Compounds }\end{array}$ & $\begin{array}{l}\text { Probably }<0.00024 \\
\text { rem } / \mu C i \text { weighted }\end{array}$ & -- & -- & -- & $\begin{array}{l}<0.030 \mathrm{Ci} \\
\text { (treat as HTO } \\
+20 \% \text { dose to } \\
\text { organic com- } \\
\text { partments) }\end{array}$ & -- & -- \\
\hline
\end{tabular}

\footnotetext{
${ }^{\mathrm{a}}$ ICRP-2 methods of calculation are used here for reasons given in Section 5.3 with $Q=1.7$.

$b_{\text {Based on }} 43 \mathrm{~kg}$ of body water (ICRP-2) and a biological half-life of 12 days. Reference man now has a biological half-life of 10 days. This would yield a urine concentration of $116 \exp (-0.693 \times 14 / 10)=44 \mu \mathrm{Ci} / \mathrm{L}$ at 2 weeks. A concentration of $28 \mu \mathrm{Ci} / \mathrm{L}$ delivers a dose rate of $100 \mathrm{mrem}$ per week to $43 \mathrm{~kg}$ of body water for $Q=1.7$.

${ }^{C}$ The new ICRP-30 assumption of only $50 \%$ additional absorption through skin would make this value 0.0003 rem/ $\mu$ Ci.

dhis value would be $0.025 \mathrm{Ci}$ by the ICRP-2 (1959) methods of calculation.

This value was calculated by multiplying the DAC in ICRP-30 by $2.4 \times 10^{3} \mathrm{~m}^{3}$ air breathed per year. The single-intake dose was then multiplied by $Q=1.7$. However, note that, in Section 5.4, a man who inhaled 18 Ci of tritium gas received a dose of 0.1 rem to body water from HTO plus an additional dose estimated as 0.006 rem from tritium gas dissolved in body fluids (using $Q=1.7$ ) and a weighted dose equivalent of $0.12 \times 0.93$ to the lungs. On this basis, the estimated dose commitment from inhaling $1 \mu \mathrm{Ci}$ of ${ }^{3} \mathrm{H}_{2}$ could be $0.22 \mathrm{rem} / 18 \times 10^{6} \mu \mathrm{Ci}=1.2 \times 10^{-8} \mathrm{rem} / \mu \mathrm{Ci}$.
} 


\section{REFERENCES}

1. National Council on Radiation Protection and Measurements, "Basic Radiation Protection Criteria," NCRP Report No. 39, Washington, D.C., 1971.

2. International Commission on Radiological Protection, "Recommendations of the International Commission on Radiological Protection," ICRP Publication 26, Pergamon Press, 0xford, 1977.

3. Code of Federal Regulations, Title 10, Part 20 (10 CFR Part 20), "Standards for Protection Against Radiation," U.S. Government Printing Office, Washington, D.C.

4. International Commission on Radiological Protection, "The Assessment of Internal Contamination Resulting from Recurrent or Prolonged Uptakes," ICRP Publication 10A, Pergamon Press, 0xford, 1971.

5. E. A. Evans, Tritium and Its Compounds, John Wiley and Sons, New York, 1974.

6. J. E. Till et al., "Tritium--An Analysis of Key Environmental and Dosimetric Questions," ORNL/TM-6990, Oak Ridge National Laboratory, Oak Ridge, Tennessee, 1981.

7. International Commission on Radiological Protection, "Report of Committee IV on Evaluation of Radiation Doses to Body Tissues from Internal Contamination Due to 0ccupational Exposure," ICRP Publication 10, Pergamon Press, Oxford, 1968.

8. Minister of National Health and Welfare of Canada, "Bioassay Guideline 2, Guidelines for Tritium Bioassay" (Draft), Environmental Health Directorate, Health Protection Branch, Radiation Protection Bureau, Brookfield Road, Ottawa, Ontario KIA ICI, Canada, 1981.

9. A. Brodsky, "Determining Industrial Hygiene Requirements for Installations Using Radioactive Material," Health Physics, Vol. 38, pp. 1155-1117, June 1980.

10. A. Brodsky and F. J. Bradley, "Radiation Protection and Regulation," in Handbook of Radioactive Nuclides, Part VIII, Yen Wang, ed., Chemical Rubber Co., Cleveland, Ohio, pp. 573-831, 1969.

11. N. V. Steere, ed., Handbook of Laboratory Safety, CRC Press, Cleveland, Ohio, 2nd ed., pp. 482-502, 1970.

12. A. A. Moghissi and M. W. Carter, eds., Tritium, Messenger Graphics, Phoenix, Arizona, 1973.

13. J. H. Tolan, "Operational Health Physics," in Proceedings of the Ninth Midyear Topical Symposium of the Health Physics Society, February 9-12, 1976, P. L. Carson, W. R. Hendee, and D.C. Hunt, eds., Denver, Colorado.

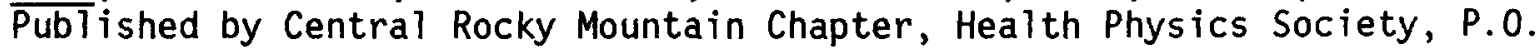
Box 3229, Boulder, Colorado, 1976. 
14. W. Seelentag, "Two Cases of Tritium Fatality," in Tritium, A. A. Moghissi and M. W. Carter, eds., Messenger Graphics, Phoenix, Arizona, pp.267-280, 1973.

15. A. Brodsky, "Experience with Intakes of Tritium from Various Processes," Health Physics, Vol. 33, pp. 94-98, 1977.

16. A. Brodsky, "Resuspension Factors and Probabilities of Intake of Material in Process (or Is 10-6 a Magic Number in Health Physics?)," Health Physics, Vol. 39, pp. 992-1000, 1980.

17. T. Franke, G. Hermann, and W. Hunzinger, "A Quantitative Estimation of the Hazards Involved in Work with Radionuclides, " in Proceedings of the First International Congress of Radiation Protection, W. S. Snyder et al., eds., Pergamon Press, London, Vol. 2, pp. 1401-1406, 1968.

18. B. A. J. Lister, comment on page 1456 in W. S. Snyder et a1. (Ref. 17); also see pp. 208-209 in E. A. Evans (Ref. 5), where an experiment is cited that showed less than $1 \mu \mathrm{C} i$ of tritiated thymine and thymidine deposited on the mask of a person processing 3 to $4 \mathrm{Ci}$ of compounds that are routinely purified by paper chromatography. This is less than 10-6 of the material in process, and consistent with the survey of accidental intakes reported by Franke et al., Reference 17.

19. R. V. Osborne, "Absorption of Tritiated Water Vapour by People," Health Physics, Vol. 12, pp. 1527-1537, 1966.

20. A. Brodsky, "Background Material for Establishing Tritium Bioassay Standards," July 20, 1976 (NRC background material on file in the Public Document Room, U.S. Nuclear Regulatory Commission, Washington, D.C., under project OP 713-4).

21. National Council on Radiation Protection and Measurements, "Tritium in the Environment," NCRP Report No. 62, Washington, D.C., 1979.

22. International Commission on Radiological Protection, "Limits for Intakes of Radionuclides by Workers," ICRP Publication 30, Part 1, Pergamon Press, Oxford, 1978.

23. National Council on Radiation Protection and Measurements, "Tritium and Other Radionuclide Labeled Organic Compounds Incorporated in Genetic Material," NCRP Report No. 63, Washington, D.C. 1979.

24. J. H. Tolan, "Criteria for Performing Bioassays for Tritium," in Sixth Campus Radiation Safety Officers' Conference, University of Houston, Houston, Texas, July 11-13, 1977. (Copies of the criteria are available from John Tolan, Radiation Safety Office, University of Missouri, 413 Clark Hall, Columbia, Missouri 65201.)

25. "Internal Dosimetry Standards for Tritium," Draft American National Standard, Draft ANSI N721, Health Physics Society Secretariat, 4720 Montgomery Lane, Bethesda, Maryland, 1979. 
26. Memorandum, R. E. Cunningham, NRC, to K. R. Goller, NRC, "Review of Responses from Chairman Graham, Health Physics Society Working Group on Internal Dosimetry Standards for Tritium, on NRC's Coordinated Comments on (Draft) ANSI N721," June 4, 1979. Available in the Public Document Room, U.S. Nuclear Regulatory Commission, Washington, D.C., under project OP 713-4.

27. Letter from W. S. Cool and J. V. Nehemias, NRC, to Health Physics Society, voting affirmative with comments on proposed ANSI N721, "Internal Dosimetry Standards for Tritium," August 8, 1979. Available in the Public Document Room, U.S. Nuclear Regulatory Commission, Washington, D.C., under project OP 713-4.

28. Memorandum, V. L. Miller, NRC, to R. E. Alexander, NRC, "Regulatory Guide for Bioassay of Tritium," March 5, 1981. Available in the Public Document Room, U.S. Nuclear Regulatory Commission, Washington, D.C., under project OP 713-4.

29. International Commission on Radiological Protection, "Report of ICRP Committee II on Permissible Dose for Internal Radiation (1959)," Health Physics, Vol. 3, June 1960.

30. H. J. Dunster, "Progress Report from ICRP," Health Physics, Vol. 17, p. $389,1969$.

31. Y. I. Moskalev et al., "Relative Biological Effectiveness of Tritium," in Tritium, A. A. Moghissi and M. W. Carter, eds., Messenger Graphics, Phoenix, Arizona, pp. 240-244, 1973.

32. H. A. Johnson, "The Quality Factor for Tritium Radiation," in Tritium, A. A. Moghissi and M. W. Carter, eds., Messenger Graphics, Phoenix, Arizona, pp. 231-239, 1973.

33. E. J. Hall, R. Oliver, and J. S. Bedford, "The Relative Biological Effectiveness of Tritium Beta Particles Compared to Gamma Radiation -Its Dependence on Dose Rate," British Journal of Radiology, Vol. 40, pp. 704-710, 1967.

34. J. S. Robertson, "Tritium Turnover Rates in Mammals," in Tritium, A. A. Moghissi and M. W. Carter, eds., Messenger Gaphics, Phoenix, Arizona, pp. 322-327, 1973.

35. A. A. Moghissi, R. G. Patzer, and M. W. Carter, "Biokinetics of Environmental Tritịum," in Tritium, A. A. Moghissi and M. W. Carter, eds., Messenger Graphics, Phoenix, Arizona, pp. 314-321, 1973.

36. R. Hal1, "Tritium Control at a Large Nuclear Facility," DPSPU 79-30-18, available from Savannah River Plant, E. I. du Pont de Nemours and Co., Aiken, S.C. 29801, 1979; also, W. C. Reinig and E. L. Albenesius, "Control of Tritium Health Hazards at the Savannah River Plant," American Industrial Hygiene Association Journal, Vol. 24, pp. 276-283, 1963. 
37. J. R. Johnson, "Estimation, Recording, and Reporting of Whole Body Doses from Tritium 0xide Exposure at CRNL," AECL-5507, Chalk River Nuclear Laboratories, Chalk River, Ontario, June 1976.

38. R. V. Osborne, "Permissible Levels of Tritium in Man and the Environment," Radiation Research, Vol. 60, pp. 197-211, 1972.

39. W. S. Snyder et a1., "Tabulation of Dose Equivalent per Microcurie-Day for Source and Target Organs of an Adult for Various Radionuclides," ORNL-5000, Oak Ridge National Laboratory, Oak Ridge, Tennessee, 1974.

40. C. L. Graham and J. R. Parlagreco, "A Computer Code for Calculating Personnel Doses Due to Tritium Exposures," UCRL-52138, Rev. 1, Lawrence Livermore Laboratory, University of California, Livermore, California, February 2, 1977.

41. International Commission on Radiological Protection, "Report of the Task Group on Reference Man," ICRP Report No. 23, Pergamon Press, Oxford, p. $346,1975$.

42. D. E. Dunning, Jr., et al., "Estimates of Internal Dose Equivalent to 22 Target Organs for Radionuclides Occurring in Routine Releases from Nuclear FuelCycle Facilities, Vol. III," NUREG/CR-0150, Vol. 3 (ORNL/NUREG/TM-190/Vol. 3), Oak Ridge National Laboratory, Oak Ridge, Tennessee, 1981.

43. K. F. Eckerman, M. R. Ford, and S. B. Watson, "Internal Dosimetry Data and Methods of ICRP - Part 2, Vo1. 1: Committed Dose Equivalent and Secondary Limits," NUREG/CR-1962, Vol. 1 (ORNL/NUREG/TM-433/VI), Oak Ridge National Laboratory, Oak Ridge, Tennessee, 1981.

44. International Commission on Radiological Protection, "Limits for Intakes of Radionuclides by Workers," ICRP Publication 30, Supplement to Part 1, Pergamon Press, 0xford, p. 5, 1979.

45. D. E. Dunning, Jr., and G. G. Killough, "A Comparison of Effective Dose Equivalent from Three Major Internal Dose Compilations," Radiation Protection Dosimetry, Vol. 1, pp. 3-9, 1981.

46. E. C. Anderson and W. H. Langham, "A Theoretical Consideration of the Hazards Associated with Acute Exposure to High Concentrations of Tritium Gas," LA-1646, Los Alamos Scientific Laboratory, Los Alamos, New Mexico, 1954.

47. E. A. Pinson and E. C. Anderson, "The Body Absorption, Distribution, and Excretion of Tritium in Man and Animals," LA-1218, Los Alamos Scientific Laboratory, Los Alamos, New Mexico, 1956.

48. E. A. Pinson and W. H. Langham, "Physiology and Toxicology of Tritium in Man," Journal of Applied Physiology: Respiratory, Environmental and Exercise Physiology, Vol. 10, pp. 108-126, 1967.

49. R. C. Weast, "Handbook of Chemistry and Physics," 55th ed., CRC Press, Cleveland, Ohio, p. 894, 1974. 
50. C. A. Tobias et al., "Symposium on Radioactive Isotopes; Uptake and Elimination of Krypton and Other Inert Gases by Human Body," Journal of Clinical Investigation, Vol. 28, pp. 1375-1385, 1949.

51. D. G. Jacobs, "Sources of Tritium and Its Behavior Upon Release to the Environment," TID-24635, Atomic Energy Commission, Washington, D.C., p. 7, 1968.

52. R. M. Standeven and D. A. Clarke, "Estimation of Radiation Doses to Tissues After Administration of Tritiated Corticosteroids to the Rat," British Journal of Radiology, Vol. 40, pp. 48-55, 1967.

53. B. E. Lambert and R. J. Clifton, "Radiation Doses Resulting from the Administration of Tritiated Folic Acid and Tritiated Water to the Rat," British Journal of Radiology, Vol. 40, p. 56, 1967.

54. J. Vennart, "Radiotoxicity of Tritium and ${ }^{14} \mathrm{C}$ Compounds," Health Physics, Vol. 16, pp. 429-440, 1969.

55. J. S. Mitchell et al., "Investigation of a Radioactive Drug (TRA 119) with Special Reference to Autoradiographic and Related Studies," Acta Radiologica, Series 2, Vol. 1, pp. 321-350, 1963.

56. L. D. Pagnatto and C. B. Killian, "Measurement of Tritiated Organic Compounds in the Presence of Tritiated Water in Urine," American Industrial Hygiene Association Journal, Vol. 30, pp. 407-412, $196 \overline{9 .}$

57. P. S. Rohwer, "Relative Radiological Importance of Environmentally Released Tritium and Krypton-85," IAEA-SM-172/76, International Atomic Energy Agency, Vienna, Austria, pp. 79-90, 1976.

58. P. S. Rohwer and H. W. Wilcox, "Radiological Aspects of Environmental Tritium," Nuclear Safety, Vol. 17, pp. 216-222, 1976.

59. L. D. Samuels, W. E. Kisieleski, and R. Baserga, "Tritiated Thymidine Toxicity in Mammalian Systems," Atompraxis, Vol. 10, No. 3, pp. 144-148, 1964.

60. R. 01iver and L. G. Lajtha, "Hazard of Tritium as a Deoxyribonucleic Acid Label in Man," Nature, Vol. 186, pp. 91-92, 1960.

61. R. J. Berry, R. 01iver, and A. B. Reiskin, "Reproductive Death of Mammalian Cells Due to Beta Radiation from Incorporated Thymidine Labelled with ${ }^{3} \mathrm{H}$ or ${ }^{14} \mathrm{C}, "$ Health Physics, Vol. 12, pp. 1461-1466, 1966.

62. L. Wade, Jr., and E. I. Shaw, "Preliminary Estimate of the Hazard from Ingestion of Tritiated Thymidine," Radiation Research, Vol. 43, pp. 403-415, 1970.

63. W. G. Van de Riet and E. I. Shaw, "A Radiation Effect from Metabolism of Tritiated Thymidine," Radiation Research, Vol. 43, pp. 416-428, 1970. 
64. D. E. Barber, "Maximum Permissible Concentrations for Tritiated Water and Tritiated Thymidine," American Industrial Hygiene Association Journal, Vol. 30, pp. 514-518, 1969.

65. W. R. Guild (letter to the editor, "Hazards from Isotopic Tracers"), Science, Vol. 128, pp. 1308, 1958.

66. W. C. Dewey, R. M. Humphrey, and B. A. Jones, "Comparison of Tritiated Thymidine, Tritiated Water and Cobalt-60 Gamma Rays in Inducing Chromosomal Aberrations," Radiation Research, Vol. 24, p. 214, 1965.

67. W. C. Dewey, R. M. Humphrey, and A. Jones, "Effectiveness of Tritiated Thymidine Compared with Tritiated Water and Cobalt-60 Gamma Rays for Induction of Chromosomal Breaks," Radiation Research, Vol. 19, p. 187, 1963.

68. B. E. Lambert, "The Biological Effect of Certain Tritium-Labelled Compounds Related to Dose," in Tritium, A. A. Moghissi and M. W. Carter, eds., Messenger Graphics, Phoenix, Arizona, p. 219, 1973.

69. B. E. Lambert, "Cytological Damage Produced in the Mouse Testes by Tritiated Thymidine, Tritiated Water, and X-Rays," Health Physics, Vo1. 17, p. 547, 1969.

70. B. E. Lambert and R. J. Clifton, "Radiation Doses Resulting from the Ingestion of Tritiated Thymidine by the Rat," Health Physics, Vol. 15, p. 3, 1968.

71. L. D. Samuels and W. E. Kisieleski, "Toxicological Studies of Tritiated Thymidine," Radiation Research. Vol. 18, pp. 620-632, 1963.

72. K. H. Garder and F. Devik, "Studies on the Incorporation of Tritiated Thymidine in Desoxyribonucleic Acid in Mouse Tissues and its Radiation Effects," International Journal of Radiation Biology, Vol. 6, pp. 157-172, 1963.

73. G. Gerber, G. Gerber, and K. I. Altman, "The Catabolism of Tissue Nucleic Acid in the Rat. I. The Replacement Time of Ribonucleic Acid," Journal of Biological Chemistry, Vol. 235, pp. 1433-1436, 1960.

74. M. Stroun et al., "Metabolic DNA in Heart and Skeletal Muscle and in the Intestines of Mice," Nature, Vol. 216, pp. 716-717, 1967.

75. S. R. Pelc, "Labeling of DNA and Cell Division in So-Called Nondividing Tissues," Journal of Cell Biology, Vol. 22, pp. 21-28, 1964.

76. V. P. Bond and L. E. Feinendegen, "Intranuclear ${ }^{3} \mathrm{H}$-thymidine: Dosimetric, Radiobiological, and Radiation Protection Aspects," Health Physics, Vol. 12, pp. 1007-1020, 1966.

77. E. P. Cronkite, J. S. Robertson, and L. E. Feinendegen, "Somatic and Teratogenic Effects of Tritium," in Tritium, A. A. Moghissi and M. W. Carter, eds., Messenger Graphics, Phoenix, Arizona, pp. 198-209, 1973. 
78. L. E. Feinendegen and V. P. Bond, "Transmutation Versus Beta Irradiation in the Pathological Effects of Tritium Decay," in Tritium, A. A. Moghissi and M. W. Carter, eds., Messenger Graphics, Phoenix, Arizona, pp. 221-231, 1973.

79. W. E. Davis and L. J. Cole, "Comparative Effects of Fast Neutrons and $X$-Rays on Marrow Deoxyribonucleic Acid (DNA) Content in Mice," Radiation Research, Vol. 14, p. 104, 1961.

80. H. A. Johnson and E. P. Cronkite, "The Effects of Tritiated Thymidine on Mortality and Tumor Incidence in Mice," Radiation Research, Vol. 30, pp. 488-496, 1967.

81. American National Standards Institute, "Performance Verification of LiquidScintillation Counting Systems," ANSI N42.15-1980.

82. American National Standards Institute, "American National Standard for Internal Dosimetry for Mixed Fission and Activation Products," ANSI N343-1978.

83. National Council on Radiation Protection and Measurements, "Operational Radiation Safety Program," NCRP Report No. 59, Washington, D.C., 1978.

84. National Council on Radiation Protection and Measurements, "A Handbook of Radioactivity Measurements Procedures," NCRP Report No. 58, Washington, D.C. , 1978.

85. A. A. Moghissi et a1., "Low-Level Counting by Liquid Scintillation, I. Tritium Measurement in Homogeneous Systems," International Journal of Applied Radiation and Isotopes, Vol. 20, pp. 145-156, 1969.

86. R. Lieberman and A. A. Moghissi, "Low-Level Counting by Liquid Scintillation, II. Applications of Emulsions in Tritium Counting," International Journal of Applied Radiation and Isotopes, Vol. 21, p. 319, 1970.

87. A. A. Moghissi et a1., "Improved Radiobioassay of Urine for Tritium," Health Physics, Vol. 17, pp. 727-729, 1969.

88. R. V. Osborne, "Studies and Techniques in Tritium Health Physics at CRNL," AECL-2699, Atomic Energy of Canada Limited, Chalk River, Ontario, 1967.

89. G. N. Stradling, "Design and Implementation of Biological Monitoring Programs for Tritium," in "Assessment of Radioactive Contamination in Man," STI/PUB/ 290, Internationa] Atomic Energy Agency, Vienna, Austria, pp. 385-402, 1972.

90. G. C. Butler, "Retention and Excretion Equations for Different Patterns of Uptake," in "Assessment of Radioactive Contamination in Man," STI/PUB/290, International Atomic Energy Agency, Vienna, Austria, pp. 495-507, 1972.

91. G. G. Killough, "Derivation of Dose Conversion Factors for Tritium," NUREG/ CR-2523, Oak Ridge National Laboratory, Oak Ridge, Tennessee, March 1982. 


\section{Abstract}

This report summarizes information and references used in developing regulatory guidance on programs for the bioassay of tritium as well as information useful in planning and conducting tritium bioassay programs and evaluating bioassay data. A review of literature on tritium radiobiology is included to provide a ready source of information useful for estimating internal doses of tritium and risks for the various tritium compounds and forms, including elemental (gaseous) tritium. Simplified and conservative dose conversion factors are derived and tabulated for easy reference in program planning, safety evaluations, and compliance determinations. 


\section{NOTICE}

\section{Availability of Reference Materials Cited in NRC Publications}

Most documents cited in NRC publications will be available from one of the following sources:

1. The NRC Public Document Room, 1717 H Street, N.W. Washington, DC 20555

2. The NRC/GPO Sales Program, U.S. Nuclear Regulatory Commission, Washington, DC 20555

3. The National Technical Information Service, Springfield, VA 22161

Although the listing that follows represents the majority of documents cited in NRC publications, it is not intended to be exhaustive.

Referenced documents available for inspection and copying for a fee from the NRC Public Document Room include NRC correspondence and internal NRC memoranda; NRC Office of Inspection and Enforcement bulletins, circulars, information notices, inspection and investigation notices; Licensee Event Reports; vendor reports and correspondence; Commission papers; and applicant and licensee documents and correspondence.

The following documents in the NUREG series are available for purchase from the NRC/GPO Sales Program: formal NRC staff and contractor reports, NRC-sponsored conference proceedings, and NRC booklets and brochures. Also available are Regulatory Guides, NRC regulations in the Code of Federal Regulations, and Nuclear Regulatory Commission Issuances.

Documents available from the National Technical Information Service include NUREG series reports and technical reports prepared by other federal agencies and reports prepared by the Atomic Energy Commission, forerunner agency to the Nuclear Regulatory Commission.

Documents available from public and special technical libraries include all open literature items, such as books, journal and periodical articles, and transactions. Federal Register notices, federal and state legislation, and congressional reports can usually be obtained from these libraries.

Documents such as theses, dissertations, foreign reports and translations, and non-NRC conference proceedings are available for purchase from the organization sponsoring the publication cited.

Single copies of NRC draft reports are available free upon written request to the Division of Technical Information and Document Control, U.S. Nuclear Regulatory Commission, Washington, DC 20555.

Copies of industry codes and standards used in a substantive manner in the NRC regulatory process are maintained at the NRC Library, 7920 Norfolk Avenue, Bethesda, Maryland, and are available there for reference use by the public. Codes and standards are usually copyrighted and may be purchased from the originating organization or, if they are Americarı National Standards, from the American National Standards Institute, 1430 Broadway, New York, NY 10018.

GPO Printed copy price: $\$ 3.75$ 